\title{
EGO FUI PER OMNIA LOCA SANCTA: HODOČAŠĆE DUBROVKINJE MARUŠE U SVETU ZEMLJU 1394. ${ }^{1}$
}

\begin{abstract}
Sjeni akademika Davora Krapca
Na temelju analize oporuke Dubrovkinje Maruše, sastavljene pri povratku s hodočašća u Svetu Zemlju 1394., ispituju se društveni krug kojem je pripadala, tijek njezina putovanja, prtljaga i „sveti predmeti“ poneseni kući te se traže odgovori i na općenitija pitanja o srednjovjekovnim hodočašćima i pobožnosti.

Ključne riječi: Dubrovnik; Sveta Zemlja; srednji vijek; hodočašće; ženska pobožnost; brandea.
\end{abstract}

Proučavanje hrvatskih hodočašća u srednjem vijeku temeljilo se poglavito na oporukama s relativno mnogobrojnim, ali sadržajno monotonim zapisima među legatima za spas duše i tek na pokojem izvoru druge vrste. ${ }^{2}$ Kao što je konstatirao Tomislav Raukar, „,...[vrela] sadrže podatke o općem okviru hodočasništva, prije svega o njegovim odredištima i stupnju njihova ugleda na hrvatskom prostoru ili o brojnosti hodočasničkih putovanja prema njima, ali najmanje ocrtavaju sáme hodočasnike i njihov duhovni obzor".

Polazište ovoga rada neobjavljena je i dosad nezapažena oporuka Dubrovkinje Maruše, sastavljena uoči smrti, na povratku s hodočašća u Svetu Zemlju 1394. ${ }^{4}$ Iza ostaviteljičinih odluka o posve pragmatičnim pitanjima koja su se na-

1 Ovaj je rad sufinancirala Hrvatska zaklada za znanost projektom broj 5106.

2 Literatura za hodočašća iz gradova istočne jadranske obale citirana je najvećim dijelom u bilješkama koje slijede. Strana literatura o hodočašćima nepregledna je, a koristan bibliografski pregled za ona u Svetu Zemlju donosi Pietro PORCASI, La letteratura di pellegrinaggio in Terrasanta nel Medioevo, u: Studi in onore di Guglielmo de' Giovanni-Centelles (ur. Errico CUOZZO), Salerno: Homo Mediterraneus, 2010., 187-210.

3 Tomislav RAUKAR, Hrvatsko srednjovjekovlje: prostor, ljudi, ideje, Zagreb: Školska knjiga i Zavod za hrvatsku povijest Filozofskog fakulteta u Zagrebu, 1997., 356.

4 Testamenta notariae, ser. 10.1, sv. 8, f. 58r-59r; vidi prilog. Svi korišteni arhivski izvori pohranjeni su u Državnom arhivu u Dubrovniku, a sva mjesta u radu na kojima nije citiran neki drugi izvor odnose se na Marušinu oporuku.. 
metnula u smrtnoj uri čita se niz obavijesti o njezinu putovanju, o društvenom krugu kojemu je pripadala, o ženskoj pobožnosti i tipično hodočasničkim obredima $\mathrm{i}$ „suvenirima“.

Nakon što su u drugoj polovici 14. stoljeća ponovno uspostavljene sigurne plovidbene i trgovačke veze s istočnim Sredozemljem, ${ }^{5}$ hodočašća Europljana u Svetu Zemlju poprimila su mnoge elemente "organiziranog putovanja“ sa standardnim itinerarom i riješenom logistikom. Međutim, takvo hodočašće nije bilo ni jeftino, ni jednostavno, ni bezopasno. Kao što pokazuju detaljni opisi Pietra Casole i Felixa Fabrija, sastavljeni stoljeće poslije Marušina putovanja, hodočasnici su bili izvrgnuti mnogim opasnostima i nedaćama, od gusarskih prepada i neprijateljskog ponašanja domaćih vlasti ${ }^{6}$ do nesnosne vrućine i morskih oluja. Kad se Fabri prije polaska oprezno raspitivao o tuđem iskustvu, hodočasnik je istaknuo da mu ne može dati savjet, jer se kod odluke o putu u Sv. Zemlju - poput onih o ženidbi i odlasku u rat - ne mogu sagledati rizici. ${ }^{7}$ Neki su dubrovački hodočasnici zaista umrli na napornome putu, naprimjer 1453. dominikanac Šimun. ${ }^{8}$ Zato su pojedinci, uoči odlaska na dalja hodočašća, znali sastaviti oporuku, kao Dubrovčani Pribil Radašinović 1445., kožar Primo 1450. i Ruža Babalio 1453., svi troje putujući na proštenje u Rim. ${ }^{9}$

Na hodočašćima u Svetu Zemlju, najzahtjevnijima i najdaljima, žene su bile manjina, pa ipak mobilnost pobožnih žena ne bi trebalo podcjenjivati: njihova se

5 Eliyahu ASHTOR, Venezia e il pellegrinaggio in Terrasanta nel basso medioevo, Archivio storico italiano, 143, 1985., 198.

6 Godinu dana nakon Marušina hodočašća u Jeruzalemu je zbog propovijedanja preobraćenja na kršćanstvo ubijen franjevac Nikola Tavelić, budući svetac. Krešimir KUŽIĆ, Hrvatska obala u putopisima njemačkih hodočasnika XIV.-XVII. st.: opora - vinorodna - kršćanska, Split: Književni krug, 2013., 184.

7 Prema Stjepan KRASIĆ, Opis hrvatske obale u putopisima švicarskog dominikanca Feliksa Fabrija (Schmida) iz 1480. i 1483/84. godine, Anali Zavoda za povijesne znanosti HAZU u Dubrovniku, 39, 2001. 156.

8 Stjepan KRASIĆ, Regesti pisama generala dominikanskog reda poslanih u Hrvatsku (1392-1600), Arhivski vjesnik, 17-18, 1975., 169, pod 81.

9 Testamenta notariae, sv. 14, f. 1v; sv. 15, f. 15r; Zdenka JANEKOVIĆ RÖMER, Na razmeđi ovog i onog svijeta: Prožimanje pojavnog i transcendentnog u dubrovačkim oporukama kasnoga srednjeg vijeka, Otium, 2, 3-4, 1994., 3. Rabljanin Toma de Cancarella 1452. sastavio je oporuku uoči odlaska u Svetu Zemlju jer se bojao brodoloma (timens naufragia). Vidi Zoran LADIĆ, Medieval Pilgrims from the Eastern Adriatic Coast to Terra Sancta and Jerusalem, u: In viaggio verso Gerusalemme: culture, economie e territori (ur. Anna TRONO, Marco Leo IMPERIALE i Giuseppe MARELLA), Salerno: Congedo Editore, 2014., 106. Za druge primjere iz Dalmacije vidi RAUKAR, Hrvatsko srednjovjekovlje, 351-352; Danko ZELIĆ, Nekoliko priloga povijesti umjetnosti 15. stoljeća u Trogiru: Samostan Sv. Križa na Čiovu, zlatar Matej Pomnenić i kapela sv. Jeronima u katedrali sv. Lovre, Peristil, 50, 2007., 67 (oporuke dva bračna para uoči hodočašća u Rim) i dokument na str. 74; LADIĆ, Medieval Pilgrims, 107; KUŽIĆ, Hrvatska obala u putopisima njemačkih hodočasnika, 169. 
hodočašća $u$ Jeruzalem prate još kroz kasnu antiku, ${ }_{10}^{10}$ a prema opisima očevidaca $\mathrm{u}$ suton srednjega vijeka bilo ih je toliko da je za njihovu spavaonicu u Jeruzalemu bila potrebna velika dvorana. ${ }^{11}$ Premda hodočasnice u srednjem vijeku nisu bile rarae aves, ${ }^{12}$ znanstvena im literatura donedavno nije posvećivala znatniju pozornost već i zato što su same vrlo rijetko prenosile svoja iskustva, zbog nepismenosti ili izostanka socijalne potrebe da zabilježe svoje putovanje. ${ }^{13}$

Unatoč tome što njihova pobožnost i odricanja na dalekom putu nisu bili manji od onih njihovih muških suputnika, odnos prema hodočasnicama nije bio lišen kontroverzi i osporavanja. „Tumarajuća žena“ javlja se i kao motiv mizoginih tropa, satira i izričitih osuda jer je hodočasnica pomicala prostorne granice namijenjene svojem spolu i iskakala iz svoje uobičajene društvene uloge. ${ }^{14}$ I slučaj hodočasnice Maruše može se pribrojiti biografijama srednjovjekovnih Dubrovkinja koje su se odvijale mimo stereotipa - prkosom državnim vlastima (Nikoleta Sorgo), samovoljnim pregovaranjem o braku (Maruša Bratosaljić) ili izgradnjom vlastitog poslovnog carstva (Filipa Mençe). Tako se i hodočasnica Maruša, usudivši se izaći iz ugodne zavjetrine obitelji, susjedstva i grada, ukrcala na hodočasnički brod, putovala po Svetoj Zemlji, kupovala robu za preprodaju, nabavljala "svete predmete“ i nakraju u smrtnome času pribrano razredila imovinu. Njezina oporuka obiluje podacima koji omogućuju da se nešto više sazna o liku i postupcima hodočasnika iz naših krajeva, pogotovo hodočasnika koji po mnogočemu nije bio "tipičan“.

\section{MARUŠIN IDENTITET I OBITELJ}

Hodočasnica Maruša očito je bila neudana jer nije identificirana kao nečija supruga ili udovica, već po majci Jakuši, supruzi Priboja Mazarak (Marussa filia Jacusse, uxoris Priboy Massarach). Na temelju imenske formule može se zaključiti

10 Za pregled literature vidi Taisiya BELYAKOVA, The role and image of the Holy Land in accounts of medieval female pilgrims, Croatica Christiana periodica, 39, 75, 2015., 3-4.

11 Leigh Ann CRAIG, 'Stronger than men and braver than knights': women and the pilgrimages to Jerusalem and Rome in the later middle ages, Journal of Medieval History, 29, 2003., 155.

U drugoj polovici 14. stoljeća na oko četvrtinu osobnih hodočašća iz Zadra odlazile su žene. Zoran LADIĆ, Prilog proučavanju hodočašćenja iz Zadra u drugoj polovici 14. stoljeća, Croatica Christiana periodica, 17, 32, 1993., 24. O „,spolnoj demokratizaciji“ dalmatinskih hodočašća u Sv. Zemlju počevši od 14. stoljeća vidi također LADIĆ, Medieval Pilgrims, 103-104.

13 Ursula GANZ-BLÄTTLER, Andacht und Abenteuer: Berichte europäische Jerusalem- und SantiagoPilger (1320-1520), Tübingen: Gunter Narr Verlag, 1990., 323; CR AIG, 'Stronger than men', 155.

14 CR AIG, 'Stronger than men', 154; Leigh Ann CRAIG, Wandering Women and Holy Matrons: Women as Pilgrims in the Later Middle Ages, Leiden-Boston: Brill, 2009., 21-78 (s nizom konkretnih primjera). 
da joj Priboj nije bio otac nego poočim. ${ }^{15} \mathrm{U}$ okolici Skadra postoji selo Mazarak, ${ }^{16}$ a prezime Mazarak (Mazarek, Mazreku) javlja se na prostoru sjeverne Albanije, Crne Gore i Grčke (Epira). ${ }^{17}$

Očuh Priboj vjerojatno je imao kćer Petrušu iz prvoga braka, koju ostaviteljica u oporuci obdaruje (Petrussa Priboi). Maruša u oporuci ostavlja legat strini Ljubni (amita mea Lubna), koja živi „u Gružu“; možda je riječ o rekluzi Ljubni koja je stanovala uz crkvicu sv. Mihajla na Lapadu, spomenutoj u oporuci Marušine majke Jakuše. ${ }^{18}$

Majka Jakuša (Iacussa de Priboe Maçarach) nadživjela je Marušu i umrla 1409. U njezinoj se oporuci spominju brojni predmeti od tkanine (rupci, pokrivači, plahte, ubrusi), ali i bala platna duga dvadeset lakata (oko 10 metara) te običan i svileni konac, ${ }^{19}$ što ukazuje na to da se u domaćoj radinosti bavila nekom vrstom tekstilne proizvodnje ili obrade (predenjem, tkanjem, šivanjem, vezom i sl.). I sama Maruša u svojoj oporuci spominje platno koje su od nje preuzeli Gradojevići i traži da se sluzi koji donese njezine stvari u Dubrovnik dade pet lakata platna, što znači da je i ona vjerojatno bila uključena u tu aktivnost, kao i mnoge druge Dubrovkinje njezina vremena. ${ }^{20}$

Marušina majka u oporuci spominje svoju kuću na općinskom zemljištu (la casa mia sovra el teren del comun), ${ }^{21}$ koja se nalazila u Petoj ulici (ruga quinta) na Prijekom, tj. u gornjem dijelu današnje Dropčeve ulice. Na tome je mjestu stanovala barem 27 godina, od 1382. do smrti 1409.22 Budući da je nadživjela sve članove svoje obitelji, oporukom je kuću ostavila na doživotno uživanje fra Pavlu Cvjetkovom, a nakon njegove smrti dominikancima, s time da se od najamnine daje stipendija za studij (in adiutorio se alguno volesse andar a studio). ${ }^{23}$ Vjerojatno je kuća u Dropčevoj bila i Marušin dom, iz kojeg je krenula put Svete Zemlje.

\footnotetext{
15 Jakuša je bila za njega udana već 1382. Knjige nekretnina dubrovačke općine (13-18. st.) (prir. Irena BENYOVSKY LATIN i Danko ZELIĆ), Monumenta historica Ragusina, sv. 7/1, Zagreb - Dubrovnik: Zavod za povijesne znanosti HAZU u Dubrovniku, 2007., 144.

Božidar VUKČEVIĆ, Izvodi iz deftera za Skadarski sandžak iz 1485. i 1497. godine, http://www. montenet.org/2001/defteri.html (pristup 26. listopada 2016). jujem Nenadu Vekariću).

Joško BELA MARIĆ, Studije iz starije umjetnosti na Jadranu, sv. II, Split: Književni krug, 2012., 69, 80, 100; Paola PIN ELLI, Tra argento grano e panni: Piero Pantella, un operatore italiano nella Ragusa del primo Quattrocento, Firenze: Firenze University Press, 2013., 58.

Testamenta notariae, sv. 9 , f. $134 \mathrm{v}$.

22

Knjige nekretnina dubrovačke općine, sv. I, 144.

Testamenta notariae, sv. 9, f. 134v.
} 


\section{MARUŠIN DRUŠTVENI KRUG}

Maruša je krenula na hodočašće na molbu Ruže Kotrulj, njezine majke Tomuše $^{24}$ i Radice Bućin, s kojima je i inače bila povezana. Drugim riječima, ona nije hodočastila u Svetu Zemlju samo iz svoje duhovne potrebe nego i u njihovo ime, pa se u njezinu slučaju isprepliću elementi osobnog i zamjeničkog hodočašća.

Ugovor o zamjeničkom hodočašću inače se znao sklapati u pismenom obliku, posebno ako su ga naručivali oporučni izvršitelji, kojima je bilo stalo do urednog obračuna izdataka. Primjerice, u rano proljeće 1349. četiri su se svećenika u dubrovačkoj kancelariji obvezala epitropima pokojnih Frane zlatara i Bratoja na hodočašća u Sv. Jakov od Compostele, Rim, svetište sv. Mihovila na Monte Sant'Angelo u Apuliji i Sv. Nikolu u Bariju. ${ }^{25}$

No, kad se zamjeničko hodočašće dogovaralo osobno, a pogotovo među prijateljima - kao što je bilo u Marušinu slučaju - nije se sastavljao pismeni sporazum već je bio dovoljan neformalniji usmeni dogovor. To ujedno otkriva i „slabo mjesto" u pokušajima kvantitativnog sagledavanja fenomena hodočašća: mnoga neće biti registrirana ni u oporukama ni u notarskim spisima. Da se Maruša na brodu nije teško razboljela i sastavila oporuku, ne bismo ni saznali za njezino putovanje u Svetu Zemlju.

Ruža Kotrulj bila je baka znamenitog Benka, kći zlatara Radina Ostojića i supruga Ruska Kotrulja. ${ }^{26}$ Kotrulji su se doselili u Dubrovnik sredinom 14. stoljeća i brzo se uspeli na društvenoj ljestvici, tako da je već Ružin suprug, doseljenik u drugoj generaciji, postao član ugledne bratovštine antunina. ${ }^{27} \mathrm{U}$ vrijeme Marušina hodočašća Ruža je bila mlađa žena, vjerojatno u svojim kasnim dvadesetima, već tada majka nekoliko djece. ${ }^{28}$ Okolnost da nije bila sastavljena notarska isprava ni bilo kakav drugi dokument za ne baš zanemarivi Ružin zajam Maruši od jednog dukata pokazuje da je među njima vladao odnos povjerenja i Maruša se zaista na smrtnome času pobrinula staviti svoje dugovanje „crno na bijelo“. Marušina bliskost s Ružom ogleda se na više mjesta u oporuci, a ponajprije u tome

\footnotetext{
24 Ime Ružine majke nije spomenuto na ovome mjestu, ali zapisano je u oporuci njezina muža i Ružina oca, zlatara Radina Ostojića (Hvalenovića). Testamenta notariae, sv. 5, f. 218v-219r. Hrvatski računovođa, 1996., 38

27 VEKARIĆ, Dubrovački rod Kotrulj, 33.

28 Udala se oko 1380. Rodila je ukupno dvanaestero djece, zadnje oko 1411. VEKARIĆ, Dubrovački rod Kotrulj, 38-39, 48.
} 
što je imenuje za izvršiteljicu oporuke. Maruša je također Ružinim djevojčicama Margariti i Nikoleti ostavila oporukom kutije sa svetim moćima. Nakon Marušine smrti njezina majka Jakuša nastavila je njegovati vezu s Ružom, što se vidi po legatima ostavljenima njoj i njezinoj kćeri Maruši, dominikanki u samostanu sv. Marije od Anđela. ${ }^{29}$

Maruša je za drugog epitropa odredila Radicu, ženu Nikole Bućin (u jednom izvoru zvan i Bućić), kojoj je ostavila i dosta vrijedan legat od jednog dukata. I Marušina majka Jakuša 1409. ostavlja Radici legat od 5 perpera, što govori o trajnoj obiteljskoj povezanosti. ${ }^{30} \mathrm{O}$ Radici je malo što poznato, osim da je umrla kao udovica 1412. Jedan od izvršitelja oporuke bio joj je Jakov, sin Ruže Kotrulj. ${ }^{31}$

Neke je od svojih „,svetih suvenira“ Maruša oporukom namijenila susjedama Cviti i Ratki, kao i nekoj Gojni i drugim osobama koje se nije moglo identificirati, a neke je, zajedno sa svojim „starim stvarima“ ostavila već spomenutoj strini Ljubni. U oporuci Maruša također traži uslugu od kožara Antuna, koji je vjerojatno bio obiteljski prijatelj, jer ga njezina majka Jakuša postavlja za epitropa, a njegovu ženu Ljubicu obdaruje. ${ }^{32}$

Premda se zbog miješanja upravnog i neupravnog govora mjestimice teško prati o čemu je riječ, iz oporuke se iščitava i jedan stari Marušin sukob s Miladnom Gradojević. Maruša na samrti izražava žaljenje zbog ružnih riječi opravdavajući se da su ih zli ljudi zavadili. Ipak Miladni za uspomenu ostavlja relikviju, ali „ne lijepu“. Kune se Bogom da jedan njezin ubrus nije prodala za više od 15 groša, pa to prebija protutražbinom, a također spominje da su Gradojevići od nje preuzeli neko platno.

Maruša je na nama nepoznat način bila povezana s plemkinjom Slavom, ženom Vole de Volço, jer joj je ta oporukom ostavila legat od 15 perpera. ${ }^{33}$ Ona je ujedno jedina žena iz plemićkog kruga koju dokumenti povezuju s Marušom.

\section{HODOČAŠĆE U SVETU ZEMLJU 1394. I MARUŠINO DRUŠTVO NA BRODU}

Pristanak hodočasničkog broda i odlazak Dubrovčana u Svetu Zemlju nisu bili svakodnevna stvar, pa su znali ostaviti poneki trag u zapisnicima vijeća, kao

\footnotetext{
29 Testamenta notariae, sv. 9, f. 134v. Međutim, prema istraživanjima Nenada Vekarića, Ruskova i Ružina kći Margarita (Maruša) bila je udana, dok je dominikanka bila kći Jeljena; u vrijeme Jakušine oporuke Jeljena je bila sitno dijete, pa se kontradikcija ne može objasniti zabunom u imenu. Usp. VEKARIĆ, Dubrovački rod Kotrulj, 41-42.

30 Testamenta notariae, sv. 9, f. $134 \mathrm{v}$.

31 Testamenta notariae, sv. 9, f. $185 \mathrm{r}-185 \mathrm{v}$.

32 Testamenta notariae, sv. 9, f. $134 \mathrm{v}$.

33 Testamenta notariae, sv. 8, f. 44r.
} 
krajem travnja 1345., kad Vijeće umoljenih sugrađanima koji kreću prema Svetoj Zemlji dodjeljuje milodare od po 18 groša (de donando et faciendo elemosinam hominibus de Ragusio qui presentialiter vadunt ad passagium). ${ }^{34}$ Nažalost, rijetko su zapisi toliko bogati i izričiti: npr. 22. svibnja 1390. Vijeće umoljenih odlučuje da se neće još slati naoružana brodica u Veneciju po poklon za bosanskog kralja već da će se pričekati prolazak hodočasnika (de expectando passagium). ${ }^{35} \mathrm{Ili}$, u proljeće 1392. izgnana Nikoleta Sorgo hodočasničkim je brodom trebala proći vodama svojeg zavičaja, što joj je dozvoljeno pod uvjetom da se ne iskrca na kopno (pro viagio quod facere intendit ad Sacrum Sepulcrum possit ire et redire per aquas nostras non descendendo in terram). ${ }^{36} \mathrm{Za}$ 1394. nemamo, nažalost, nikakvu "službenu vijest", jer zapisnici dubrovačkih vijeća iz te godine nisu sačuvani.

Najuglednijim i najbogatijim hodočasnicima u Veneciji ustupane su na besplatno korištenje ili davane u najam zasebne galije. ${ }^{37}$ Među prvima je naprimjer bio zagrebački biskup Pavao Horvat, ${ }^{38}$ dok je bogati Nikola Frankapan sa svojom svitom 1411. mletački brod unajmio. ${ }^{39} \mathrm{No}$, većina je putnika u Svetu Zemlju plovila posebnim hodočasničkim brodovima, koji su potkraj 14. stoljeća obično prevozili 50 - 100, pa i do 160 putnika. Pritisak hodočasnika na mletačku luku bio je tolik da su hodočasnike uzimali i na brodove koji su plovili u trgovačkom konvoju u istočno Sredozemlje i koji su se specijalno iz tog razloga sidrili i u Jafi. ${ }^{40}$

Zbog pristajanja tih brodova u Dubrovniku, ${ }^{41}$ domaćim se hodočasnicima redovito ukazivala prilika za polazak prema željenom odredištu. Maruša se si-

34 Libri reformationum, sv. I (prir. Ivan Krstitelj TKALČIĆ), Monumenta spectantia historiam Slavorum Meridionalium, sv. X, Zagreb: JAZU, 1879., 174.

35 Odluke dubrovačkih vijeća 1390-1392 (prir. Nella LONZA i Zdravko ŠUNDRICA), Zagreb - Dubrovnik, Zavod za povijesne znanosti HAZU u Dubrovniku, 2005., 94.

Odluke dubrovačkih vijeća 1390-1392, 361; odluka Malog vijeća: ibidem, 198.

Margaret NEWETT, Introduction, u: Canon Pietro Casola's Pilgrimage to Jerusalem in the Year 1494, Manchester: Manchester University Press, 1907., 31-36. Neki od tih uglednih putnika, koji su se sa svojom pratnjom koristili zasebnim brodom, pristali su u Dubrovniku. O njihovim posjetima gradu vidi Jorjo TADIĆ, Promet putnika u starom Dubrovniku, Dubrovnik: Turistički savez u Dubrovniku, 1939., 161-162; Mladen IBLER, Putovanje skandinavskog kralja Erika VII Pomeranskog kroz Hrvatsku 1424.-1425., Anali Zavoda za povijesne znanosti HAZU u Dubrovniku, 39, 2001., 127, 129. NEWETT, Introduction, 32; KUŽIĆ, Hrvatska obala u putopisima njemačkih hodočasnika, 167-168. Zoran LADIĆ, Hodočašća kao izraz pobožnosti stanovnika kasnosrednjovjekovne porečke komune, Histria, 5, 2015., 17.

40 ASHTOR, Venezia e il pellegrinaggio in Terrasanta, 202, 205, 213. Za podatke o broju putnika po plovidbi i ukupno, vidi NEWETT, Introduction, 36-39.

41 Niz primjera za srednji vijek donosi TADIĆ, Promet putnika: 179-200. Poznat je samo jedan slučaj iz 1377., kada je dubrovački brod prevozio hodočasnike u Jafu, ali izgleda da ih je ukrcao u Valoni. Constantin JIREČEK, Die Bedeutung von Ragusa in der Handelsgeschichte des Mittelalters, Wien: K. K. Hof- und Staatsdruckerei, 1899., 85-86; KUŽIĆ, Hrvatska obala u putopisima njemačkih hodočasnika, 179 . 
gurno ukrcala na "pravi“ hodočasnički brod, jer trgovački konvoji nisu plovili ljeti. ${ }^{22}$ Redovito je iz Dubrovnika zajedno kretalo više hodočasnika. Primjerice, potkraj 15. stoljeća po dva su Dubrovčanina putovala u društvu sa švicarskim dominikancem Fabrijem i s milanskim kanonikom Casolom. ${ }^{43}$

S Marušom su 1394. istim brodom plovili svećenici Nikola i Andrija, koji je tada služio na Lastovu, ${ }^{44}$ obojica i iz Pultske biskupije (de Polato) u zapadnoj Albaniji. U Dubrovniku je $u$ to vrijeme sve vrvjelo svećenicima s albanskih područja, koji su izbjegli pred osmanskim naletima, a iz Pultske biskupije bilo ih je 1386. barem pet. ${ }^{45}$ Nikola i Andrija bili su svjedoci Marušine oporuke i pred sudom iskazali su koja je bila njezina posljednja volja.

S njima je također putovao na hodočašće Božić, bivši sluga Marina Klementovog Goçe zvanog Goçcho (Bosichus qui fuit puer de ser Goç̧icho). ${ }^{46}$ Njemu je Maruša povjerila većinu osobnih stvari s molbom da ih preda njezinoj majci Jakuši. Tražila je od epitropa da se Božiću od njenoga nabave košulja, hlače i rubac (una camisia, unus par braciis et unum sudarium), iz velike zahvalnosti što ju je u bolesti njegovao „kao brat“ (quia fuit mihi sicut frater in infirmitate mea).

Budući da je Maruša nakon 19. kolovoza umrla na brodu koji se vraćao iz Svete Zemlje, a putovanja su obično trajala mjesecima ${ }^{47}$ može se procijeniti da je brod iz matične luke Venecije isplovio negdje u lipnju. Marušina je posljednja volja ovjerena i unesena u službene knjige oporuka tek 3. studenog 1394., a na

$\overline{42}$ ASHTOR, Venezia e il pellegrinaggio in Terrasanta, 213.

43 KRASIĆ, Opis hrvatske obale u putopisima švicarskog dominikanca Feliksa Fabrija, 162; Pietro CASOLA, Canon Pietro Casola's Pilgrimage to Jerusalem in the Year 1494, Manchester: Manchester University Press, 1907., 257; vidi također L ADIĆ, Hodočašća kao izraz pobožnosti, 20 i ondje cit. literaturu. Može se dometnuti da je i među veslačima hodočasničkih galija ponekad bilo Dubrovčana, kao 1414. petorica iz Dubrovnika i petorica iz Stona; no to su uglavnom bili dubrovački iseljenici, nastanjeni u Veneciji. Neven BUDAK, Putovanje Ivana VIII. Paleologa i patrijarha Josipa II. duž istočne jadranske obale, u: Spalatumque dedit ortum, Zbornik povodom desete godišnjice Odsjeka za povijest Filozofskog fakulteta u Splitu (ur. Ivan BASIĆ i Marko RIMAC), Split: Filozofski fakultet u Splitu - Odsjek za povijest, 2014., 279-280.

U oporuci je označen samo kao svećenik Andrija s Lastova, no iz ugovora o službi u crkvi sv. Ivana Krstitelja koja se gradila na Lastovu od 5. ožujka iste godine vidi se da je riječ o Nikoli Ianiçe iz Pultske biskupije (de Polato). Diversa notariae, ser. 26, sv. 10, f. 102v-103r.

Distributiones testamentorum, ser. 10.2, sv. 5, f. 8r.

Irmgard MAHNKEN, Dubrovački patricijat u XIV veku, sv. I, Beograd: SANU, 1960., 244; Nenad VEKARIĆ, Vlastela grada Dubrovnika, sv. VII, Genealogije (A-L), Zagreb - Dubrovnik: Zavod za povijesne znanosti HAZU u Dubrovniku, 2016., 512.

47 Putovanje je obično trajalo mjesecima, od čega je nekoliko tjedana otpadalo na boravak u Svetoj Zemlji (MeMO project, Representations of Jerusalem pilgrims, http://memo.hum.uu.nl/jerusalem/ pages/pilgrimage.html, pristup 26. listopada 2016). Naprimjer 1507. hodočasnički je brod putovao od Venecije do Jafe pedeset dana. Reinhold RÖHRICHT, Deutsche Pilgerreisen nach dem Heiligen Lande, Innsbruck: Wagner'schen Universitäts-Buchhandlung, 1900., 204. 
temelju toga što se usmena oporuka sačinjena izvan Dubrovnika morala registrirati u roku od mjesec dana po povratku svjedoka, ${ }^{48}$ hodočasnički je brod vjerojatno pristao u Dubrovniku negdje tijekom listopada. Svjedoci oporuke nisu ništa spomenuli o tome kad je Maruša točno umrla i što je bilo s njezinim tijelom, a sudac ih o tome ništa nije pitao jer to nisu bile relevantne obavijesti za ovjeru. Maruša je vjerojatno umrla tijekom plovidbe i nakon uobičajenog obreda njezino je tijelo jamačno bačeno u more. ${ }^{49}$

\section{MARUŠINA POSLJEDNJA VOLJA I INVENTAR OSOBNIH STVARI}

Predosjećajući da joj se bliži smrtna ura, Maruša je 19. kolovoza 1394., već jako bolesna (multum infirma corpore), iskazala svoju posljednju volju pred svjedocima u formi usmene oporuke. Uz oporuku su ovjerene dvije cedulje koje su svjedoci predali sucima: priznanje duga Ruži Kotrulj od jednog dukata i inventar Marušinih stvari na brodu, sastavljen nedugo prije njezine smrti. Djelomični upravni govor i neki izrazi iz tih cedula sugeriraju da ih je Maruša sama pisala (ego Marussa... sicut scribo), što u to vrijeme za osobu njezina spola i staleža nije bilo samo po sebi razumljivo. ${ }^{50}$

Marušine oporučne raspoložbe počinju uobičajenim sitnijim legatima katedrali za prvine i desetinu te crkvi sv. Vlaha. Sitni iznos ostavljen je iz pobožnosti Sv. Leonardu (in Sancto Leonardo), crkvici koja se nalazila na prijelazu Boninova prema Lapadu, uz koju je još 1279 . zabilježen rekluzorij. ${ }^{51}$ Čini se da je pobožnost prema Sv. Leonardu imala i obiteljsku podlogu, jer je i Marušina majka Jakuša ostavila legat za rekluzu Radoslavu koja je ondje živjela. ${ }^{52}$ Maruša se u oporuci također spomenula dominikanaca, kojima je ostavila pobožni legat za misu

$\overline{48}$ Liber statutorum civitatis Ragusii (prir. C. JIREČEK i V. BOGIŠIĆ), Monumenta historico-juridica Slavorum Meridionalium, sv. IX, Zagreb: JAZU, 1904., L. III, c. 42.

O praksi s kraja 15. stoljeća da se tijela hodočasnika umrlih na pučini nakon obreda bacaju u more vidi CASOLA, Canon Pietro Casola's Pilgrimage to Jerusalem, 303; Krešimir KUŽIĆ, Nordijski hodočasnici u hrvatskim primorskim krajevima, Povijesni prilozi, 49, 2015., 136.

50

Zdenka Janeković Römer prosuđuje da su u drugoj polovici 15. stoljeća „mnoge žene... znale pisati i računati“ te da su opismenjene u roditeljskom domu ili nakon udaje. Zdenka JANEKOVIĆ RÖMER, Maruša ili suđenje ljubavi: Bračno-ljubavna priča iz srednjovjekovnog Dubrovnika, Zagreb: Algoritam, 2007., 45-46.

51 Spisi dubrovačke kancelarije, sv. I (prir. Gregor ČREMOŠNIK), Zagreb: JAZU, 1951., 30, br. 114; 121, br. 422. O dubrovačkim rekluzorijima vidi Nella LONZA, The houses of recluse (reclusoria) in the urban and suburban setting of medieval Dubrovnik, u: Scripta in honorem Igor Fisković. Zbornik povodom sedamdesetog rođendana (ur. Miljenko JURKOVIĆ i Predrag MARKOVIĆ), Zagreb - Motovun: Međunarodni istraživački centar za kasnu antiku i srednji vijek, 2016., 301-307. 
(missa conventualis) i objed (prandium). ${ }^{53}$ Bogatim legatom od jednog dukata sjetila se svog ispovjednika, fra Jakova Šibenčanina. ${ }^{54}$ Tražila je također da se za njezinu dušu naruče gregorijanske mise i da se po mogućnosti služe $u$ istome danu.

Glavninu osobnih stvari Maruša je ostavila majci Jakuši: pojas (cingulum), naušnice (obodcii) ${ }^{55}$ i nove pokrivače (copertoria). Bude li ona već mrtva, odredila je da pripadnu Ruži, ženi Ruska Kotrulja, kao supsidijarnoj nasljednici. Ruža joj je očito bila bliska prijateljica, pa joj je ostavila i privjesak u obliku križa da ga nosi za uspomenu i da se spomene njezine duše (crocem pro amore quod portet et quod habeat animam meam in mente).

Nadživi li je majka, ono što ostane kad se ispune legati trebalo joj je pripasti u puno vlasništvo kojime može slobodno raspolagati. Ta je želja izrečena formulom vivat sicut mater et domina mea, koja u ovom slučaju poprima značenje imenovanja nasljednika. ${ }^{56}$

Zahvaljujući tome što je sastavljen inventar njezinih stvari na brodu, može se utvrditi što je Maruša nabavila u Svetoj Zemlji i što je od životnih potrepština nosila sa sobom (res... quas habuit secum in galea). Kao obično, stvari koje se nabrajaju nije uvijek moguće precizno definirati, jer za predmete svakodnevne uporabe ni specijalizirani rječnici ne nude uvijek adekvatno rješenje. U ovom je izvoru dodatni problem što se prepisivalo s ceduljice, pa je već prepisivač unosio greške. ${ }^{57}$

Na putu je imala uza se četiri košulje koje su se nosile uz tijelo, ispod „vanjskog“" odjevnog sloja (camisie), ${ }^{58}$ suknenu haljinu (carpeta), tuniku zvanu kodma-

53 O raširenom običaju ostavljanja pobožnog legata za objed, s dubrovačkim primjerima, vidi Zoran LADIĆ, Legati kasnosrednjovjekovnih dalmatinskih oporučitelja kao izvor za proučavanje nekih oblika svakodnevnog života i materijalne kulture, Zbornik Odsjeka za povijesne znanosti Zavoda za povijesne i društvene znanosti HAZU, 21, 2003., 15.

Jakov Šibenčanin bio je dominikanac, kao što se vidi iz Distributiones testamentorum, sv. 5, f. 115v. se lančićem pričvršćivale za veo i bile su znak da je žena udana. Filip de DIVERSIS, Opis slavnoga grada Dubrovnika (prir. i prev. Zdenka JANEKOVIĆ RÖMER), Zagreb: Dom i svijet, 2004., 92 i 175. Znak bračnog statusa Diversi vjerojatno nije točno „iščitao“ iz društvene prakse (usp. napomenu Z. Janeković Römer, 92, bilj. 111), a to se vidi i na Marušinu primjeru, jer ništa ne upućuje na mogućnost da je ikada bila udana. O obocima i ženskom oglavlju v. također Žarko MU LJAČIĆ, Iz dubrovačkog leksika, Linguistica, 12, 1, 1972., 130-134.

O drugačijem značenju slične formule kod oporuke u korist supruge (domina et patrona) vidi Zdenka JANEKOVIĆ RÖMER, Rod i Grad: Dubrovačka obitelj od XIII do XV stoljeća, Dubrovnik: Zavod za povijesne znanosti HAZU, 1994., 133.

Primjerice, napisao je prvo „scutellas quinque de capro“, a zatim ispravio u „de cipro“, dok je originalu po svoj prilici stajalo "de cupro“; prepisao je prvo "storfil“, pa ispravio u "forfice“; unio je riječ "clu“, koja ne znači ništa (ni kao broj), a možda je u originalu stajalo „cinguli“ s oznakom za kraćenje iznad. 
nica (tunica que dicitur codmaniça), ${ }^{59}$ dva prsluka (duo coretta), ogrtač (capa), pojas s torbicom za novac, nožićem i srebrnim križem (cingulum cum bursa et cultello et cruce argentea) - predmetima koji su joj na putu mogli dobro poslužiti - te par cipela (sutelarii). Također je imala pokrivalo za glavu (copertura capitalis), nejasno je je li to bila kapa ili pokrivača, u kojem je bilo pohranjeno brašno. Od ostalih predmeta za osobnu uporabu spomenuti su jastuk (capitale), ${ }^{60}$ jastučnice (cusini), ubrusi (tobalee), ${ }^{61}$ pokrivač (lodix), bisage (par bisanciarum), jedna bakrena čaša (schiphum de cupro) i jedna staklena (sciphum vitreum), pet plitica (scutelle quinque), bačvica (barile), ${ }^{62}$ vrč (urceum) i škare (forfice). Za popudbinu je imala vreću s kruhom (saccus I cum pane) i već spomenuto brašno, možda za kuhanje kaše. ${ }^{63}$

Maruša je svoje hodočasničko putovanje iskoristila za usputnu trgovinu, kao što su činili i mnogi drugi hodočasnici prije nje. ${ }^{64} \mathrm{U}$ jednoj je škrinji nosila tri libre (oko $1 \mathrm{~kg}$ ) pamuka, vjerojatno namijenjenog vlastitoj preradi ili preprodaji. U to se vrijeme u Dubrovnik pamuk uglavnom uvozio iz Apulije, ${ }^{65}$ ali Dubrovčani su trgovali i kvalitetnijim levantskim pamukom. ${ }^{66}$ Maruša je također nabavila papar, skupi začin koji se moglo dobro prodati na dubrovačkom tržištu ${ }^{67}$

59 Codmaniça, ženski odjevni komad, spominje se i u Distributiones testamentorum, sv. 5, f. 31v.

Lexicon latinitatis medii aevi iugoslaviae, sv. I (ur. Marko KOSTRENČIĆ), Zagreb: JAZU, 1969., 171; Spisi dubrovačke kancelarije, sv. II (prir. Josip LUČIĆ), Zagreb: JAZU, 1984., 360, br. 1325; izvjesnu nedoumicu u identifikaciji tog predmeta unosi nastavak „cum dimidio“.

61 Na drugome se mjestu spominje ubrus dug dva lakta (tobalea de duabus brachiis), koji možda ima drugu funkciju. Također je moguće da su neki od tih ubrusa ustvari brandea (v. niže).

Bačvice s vodom i vinom bile su standardni dio hodočasničke opreme. NEWETT, Introduction, 11, 25; H. F. M. PRESCOTT, Jerusalem Journey: Pilgrimage to the Holy Land in the Fifteenth Century, London: Eyre \& Spottiswoode, 1954., 53.

Hodočasnicima je na brodu bila osigurana hrana, uključena u cijenu prijevoza, no savjetovalo se da se ponese i nešto brašna, drva za loženje vatre (!), kruh, dvopek i, prema mogućnostima, luksuznije namirnice. PRESCOTT, Jerusalem Journey, 53-54.

64 Još za 12. stoljeće znamo da su neki hodočasnici prodavali ponesene stvari za financiranje svog hodočašća. David JACOBY, The Economic Impact of Christian Pilgrimage on the Holy Land, Eighth-Sixtheenth Century - A Long-Term Overview, u: Religione e istituzioni religiose nell'economia europea, 1000-1800 (ur. Francesco AMMANNATI), Firenze: Firenze University Press, 2012., 703.

Josip LUČIĆ, Gospodarsko-društveni odnosi u Dubrovniku u Stojkovićevo vrijeme, Historijski zbornik, 38, 1985., 102.

Na srednjovjekovnom tržištu zapadnoeuropski pamuk iz Apulije, Kalabrije i Sicilije vrijedio je daleko manje od levantskog pamuka, koji se, između ostaloga, izvozio preko „hodočasničke“ luke Jafe. Vidi Maureen F EN N L L MAZZAOUI, The Italian cotton industry in the later Middle Ages 1100 1600, Cambridge (itd.): Cambridge University Press, 1981., 28-55, osobito 37, 43.

67 Kao skupocjenost, papar se poklanjao u službenim prigodama. Primjerice, 1438. dubrovačke vlasti daruju papar u vrijednosti od 10 perpera izaslanicima vojvode Radoslava Pavlovića. Mihailo J. DINIĆ, Iz dubrovačkog arhiva, sv. III, Beograd: Naučno delo, 1967., 226-227. 
Rad Hrvat. akad. znan. i umjet. Razred za druš. znan. 52=529(2017) : 95-122

\section{„VELIKA“, „MALA“ I „NAJMANJA“ HODOČAŠĆA U MARUŠINOJ OPORUCI I DUBROVAČKOJ SREDNJOVJEKOVNOJ PRAKSI}

Velikim hodočašćima (peregrinationes maiores) u srednjem su se vijeku smatrala ona u Svetu Zemlju, Rim i Sv. Jakov od Compostele. Ni oporuke ni ugovori o zamjeničkom hodočašću, nažalost, ne mogu ponuditi realnu sliku o njihovoj frekvenciji, jer su jednostavnija i jeftinija hodočašća u regionalna i lokalna svetišta ostavljala manje traga $u$ pisanim izvorima. ${ }^{6}$

U godinama oko Marušina putovanja ima i drugih slučajeva da se oporukom ostavlja legat za hodočašće u Svetu Zemlju. Primjerice, Ivan, kapelan Sv. Mihovila od Pakljene na Šipanu, 1391. ostavlja za tu namjenu 45 dukata izražavajući želju da na hodočašće pođe brat Đuro iz mljetskog samostana, ${ }^{69}$ kojem su epitropi 1392. zaista isplatili 42 dukata. ${ }^{70} \mathrm{U}$ zadnjem desetljeću 15. stoljeća hodočašća na Sv. Grob spominju se u osam oporuka. ${ }^{71}$

Maruša ostavlja i dukat za hodočašće u Sv. Jakov od Compostele i u Rim, kamo se kanio uputiti fra Benedikt, s time da mu se legat isplati tek po povratku.

U istočnojadranskim gradovima, pa tako i u Dubrovniku, bila su također vrlo popularna „manja hodočašća“ (peregrinationes minores), kao što su ona u Assisi, Bari i Monte Sant'Angelo na Garganu. ${ }^{72}$ Iz Dubrovnika se također odlazilo u još bliža prošteništa, naprimjer u Sv. Mariju Ratačku, benediktinsku opatiju pokraj Bara. ${ }^{73}$

Velika većina hodočašća slijedila je te matrice i tek bi se rijetko dogodilo da je netko odabrao neko drugo odredište. Primjerice, Ivan Ogrea namijenio je 1380. legate za hodočašća u Sv. Jakov od Compostele, Sv. Nikolu u Bariju, Monte Sant'Angelo na Garganu, no također za odlazak u svetište Montevergine kraj Napulja. ${ }^{74}$ Trgovac Maroje Sisa 1363. ostavlja legate za hodočasnike na uobičajena mjesta, ali i u Sv. Veneru (Petku) u Velikom Trnovom (Bugarska). ${ }^{75}$ Još je neo-

\footnotetext{
68 Na temelju zadarskih oporuka iz druge polovice 14. stoljeća izgledalo bi kao da je oko tri četvrtine hodočašća bilo u Rim, Jeruzalem i Sv. Jakov od Compostele. LADIĆ, Prilog proučavanju hodočašćenja iz Zadra, 24.

primjere dubrovačkih hodočašća u tu opatiju vidi Savo M ARKOV IĆ, Studia Antibarensia, Perast:
Gospa od Škrpjela, 2006., 171-172, gdje se donosi i detaljan historijat prošteništa s pregledom starije
literature (119-179).

74

75
} 
čekivaniji bio izbor Klementa Marinova Gozze, koji je 1394. ostavio 40 dukata za odlazak na hodočašće na grob sv. Thomasa Becketa u katedrali u Canterburyju zbog zavjeta koji je učinio za spas brata Luja. ${ }^{76}$

Opći motiv za hodočašća jest pobožnost za vlastitu dušu i dušu bližnjih (pro anima, per anima deli mei morti e mia). ${ }^{77}$ Neka su hodočašća bila usmjerena prema dobivanju oprosta na određeni blagdan ili u jubilarnoj godini (perdon, perdonança, perdonança grande) ${ }^{78}$ a u nekim se slučajevima spominje položeni zavjet. ${ }^{79}$ Oni koji nisu mogli ili nisu željeli sami poći na hodočašće slali su zamjenike, često dijecezanske svećenike te dominikance i franjevce. ${ }^{80} \mathrm{Od}$ osobe koja odlazi na zamjeničko hodočašće ponekad se izričito tražio obilazak svetih mjesta (le cerche che se fa a luoghi sancti), molitve (pregar Dio per anima mia), a ako je svećenik - i služenje sv. misa za ostaviteljevu dušu (dir messe per anima mia). ${ }^{81}$

Oporučitelj je ponekad ostavljao cijelu svotu potrebnu za hodočašće, ${ }^{82}$ a nekad samo dio, pa su se sitnije svote zbrajale, ${ }^{83}$ nekad je izvršiteljima oporuke ostavljeno da isplate koliko smatraju primjerenim, odnosno koliko „pogode“ sa

76 Item lasso che se debia trovar I persona et darli ducati XL d'oro e che vada a visitar el corpo de Sancto Thomaso de Conturbino, et questo perche feci voto quando Aluyse era preson de misier Tristano et che s'el dito sera afrancha, che visiti o faça visitar il deto sancto corpo. Testamenta notariae, sv. 8, f. 93v. Iz marginalne bilješke razabire se da je legat ostao neispunjen i da ga je tek 1630. dubrovački biskup prenamijenio za gradnju dominikanskog samostana u Župi.

77 Testamenta notariae, sv. 8, f. 44r, 47v, 109v.

78 Vezano uz jubilej iz 1350.: Gordan RAVANČIĆ, Vrijeme umiranja: Crna smrt u Dubrovniku 1348. 1349., Zagreb: Hrvatski institut za povijest, 2010., 165-169, 171-172, 174, 180 i dalje. Krajem 14. stoljeća Dubrovčani su hodočastili i u Sv. Mariju od Anđela (Porcijunkulu) kraj Assisija, crkvu koja je bila poznata upravo po oprostima. Testamenta notariae, sv. 8, f. 44r (al perdon de Asiso... che vien del mexe d'agosto), 125r-125v; o hodočašćima u to svetište, vidi Jonathan SUMPTION, Pilgrimage: An Image of Mediaeval Religion, London: Faber \& Faber, 1975., 142-143.

Testamenta notariae, sv. 8, f. 87r-87v; sv. 15, f. 81v. Gojan Bolojević je 1390. ostavio 100 perpera za hodočašće u Sv. Jakov od Compostele za ozdravljenje svog strica ili ujaka Ostoje (per cura de Hostoia... mio barba; Testamenta notariae, sv. 8, f. 63r-63v). O zavjetnim hodočašćima vidi SUMPTION, Pilgrimage, 138-140.

Naprimjer Testamenta notariae, TN, sv. 8, f. 5r, 44r, , 47v, 52r, 136r-136v, 150r, 184r; sv. 16, f. 96r; Distributiones testamentorum, sv. 28, f. 166r. Kužić navodi da su redovnici češće odlazili na hodočašća i zbog toga što su morali plaćati dvostruko manje od drugih (KUŽIĆ, Hrvatska obala u putopisima njemačkih hodočasnika, 174) upućujući na Kolanovićev rad o šibenskim hodočašćima, no na tome mjestu o tome nema ničega.

Testamenta notariae, sv. 8 , f. 44 r.

Testamenta notariae, sv. 8, f. 153r, 184r; sv. 15, f. 81v; Distributiones testamentorum, sv. 5, f. 104r. Katarina, udovica Martina Dobrićevića ostavila je 1456. 100 dukata bratu Andriji iz Stona za troškove hodočašća u Jeruzalem, a što mu pretekne smije potrošili na knjige i ostalo što mu treba (Testamenta notariae, sv. 16, f. 96r).

83 Testamenta notariae, sv. 8, f. 74v, 100v (in aido dela spexa); Distributiones testamentorum, sv. 5, f. 52r sv. 28 , f. 166 r. 
zamjeničkim hodočasnikom. ${ }^{84}$ Često se na istome putu hodočastilo u Sv. Nikolu u Bariju i u nedaleko svetište Monte Sant'Angelo, a ponekad još i u Assisi. ${ }^{85}$ Trošak za hodočašće bio je proporcionalan udaljenosti odredišta i u dubrovačkim izvorima s kraja 14. i početka 15. stoljeća kreće se oko 4,5-6 dukata za hodočašća u Bari i Monte Sant'Angelo, 7 - 12 dukata za proštenje u Rimu i 30 - 35 dukata za hodočašće u Sv. Jakov od Compostele. ${ }^{86}$ Za put u Svetu Zemlju zamjeničkom se hodočasniku plaćalo 30 - 50 dukata, ${ }^{87}$ što je bio znatan iznos: približno u isto vrijeme vrijednost kuće na elitnoj lokaciji na Placi procijenjena je na 480 perpera (144 dukata), a kancelaru Andriji iz Bergama nudila se plaća od 100 dukata godišnje uz naknadu troška stanovanja. ${ }^{88}$ Zapisi oporučnih izvršitelja i ugovor o zamjeničkom hodočašću iz 1447. pokazuju da se hodočasnika često plaćalo u više obroka, sa zadnjom isplatom po povratku..$^{89}$

Sudeći po dostupnim podacima, Dubrovkinje su u srednjem vijeku općenito vrlo rijetko hodočastile izvan zavičaja, a zamjeničke hodočasnice putovale su samo za dušu drugih žena: Kate, žena Nikole Derse, ostavila je 1348. legat za hodočašće dviju žena na Monte Sant'Angelo i u Sv. Nikolu u Bariju, ${ }^{90}$ a 1416. Radica, udovica Bogavca Milatovića, prima svotu iz legata Pribislave, udovice Nikše Pribojevića za hodočašće na ta ista mjesta. ${ }^{91}$ Hodočašća Nikolete Sorgo i Maruše u Svetu Zemlju i po tome su bila izuzetna.

Osim tih „,velikih“ i „malih“ hodočašća - od kojih su i ona bliža, talijanska, tražila znatne napore i novac - postojala su i lokalna proštenja, na koja se išlo iz pokore, osobno ili preko posrednika. Naprimjer 1348. Draže, žena Ruska Sorenta, ostavlja perper da neka žena pođe bosa u crkvicu na vrhu Srđa, u Sv. Mariju

\footnotetext{
$\overline{84}$ Testamenta notariae, sv. 8, f. 44r, 52r, 150r.

Distributiones testamentorum, sv. 5, f. 13r, 33v.

Testamenta notariae, sv. 8, f. 125r-125v; Distributiones testamentorum, sv. 5, f. 10r, 51r-51v, 71v, 153r $158 \mathrm{r}, 162 \mathrm{a}-\mathrm{v}, 165 \mathrm{v}, 175 \mathrm{v}, 189 \mathrm{v}, 193 \mathrm{v}, 195 \mathrm{v} ;$ sv. 6, 37r. Za podatke iz izvora drugih dalmatinskih gradova, vidi Josip KOLANOVIĆ, Prilog povijesti šibenskih hodočašća u kasnom srednjem vijeku, Croatica Christiana periodica, 6, 9, 1982., 34; LADIĆ, Prilog proučavanju hodočašćenja iz Zadra, 25-26; RAUKAR, Hrvatsko srednjovjekovlje, 354.

Testamenta notariae, sv. 8, f. 46r; Distributiones testamentorum, sv. 5, f. 189v; sv. 6, f. 37r. Sredinom 15. stoljeća iznosi se penju i na 100 dukata (Testamenta notariae, sv. 15, f. 81v; sv. 16, f. 96r).

Odluke dubrovačkih vijeća 1390-1392, 79-80, 88.

Distributiones testamentorum, sv. 5, f. 51r-51v, 158r. Jakov Matov iz Stona obvezuje se 1447. epitropima Miha kožara da će za 10 dukata poći na hodočašće u Rim; pola iznosa mu se isplaćuje unaprijed a pola kad se vrati i podastre potvrde (Diversa notariae, sv. 30, f. 158r). Za Šibenik u 15. stoljeću usp. KOLANOVIĆ, Prilog povijesti šibenskih hodočašća, 34, za Hvar LADIĆ, Hodočašća kao izraz pobožnosti, 21.

90 Testamenta notariae, sv. 5, f. 26v; RAVANČIĆ, Vrijeme umiranja, 180 (s pogrešnom transkripcijom imena ostaviteljice i pogrešnim naslovom).

91

Distributiones testamentorum, sv. 7, f. 200r.
} 
Magdalenu u Župi i u Sv. Vlaha na Gorici. ${ }^{92}$ Ciprijan Petrov Lucari 1431. je ostavio novce da muškarac ode $\mathrm{u}$ halji bos (uno homo scalzo in camesa) u Sv. Mariju na Nuncijati i do Sv. Jakova od Višnjice, a 1446. Tamara, udovica Ivana Goçe, šalje svećenika u Sv. Kuzmu i Damjana kraj Trstenog. ${ }^{93}$ Još 1484. svećenik Toma Radanov Strujić spominje svoju namjeru da pođe bos do Sv. Jakova od Višnjice (debo andare San Jacomo alle Ploze descalzo) i oporučno određuje da netko to izvrši umjesto njega. ${ }^{94}$

Pobožna hodočašća u lokalne crkvice radi pokore i oprosta sigurno su bila mnogo raširenija nego što nam to otkrivaju oporuke i drugi arhivski izvori. Upala su u oči i Filippu Diversiju, koji je u svome Opisu Dubrovnika tu praksu skicirao kao tipično žensku. Osupnuli su ga napori tih žena po stjenovitim i brdovitim stazama, ${ }^{95}$ a nema sumnje da je obilazak nekih od tih crkvica - pogotovo one na Srđu - bio zahtjevan.

Tako je i Maruša za vlastitu pokoru (penitencia) kanila poći do Sv. Jakova od Višnjice i cijeli dan šutjeti, a kako tu nakanu nije ostvarila, oporučno je zamolila Radoslavu, ženu Obrada Arsuka, da pođe na to hodočašće, ostavivši joj dva perpera. Zatražila ju je također da, kao čin milosrđa, od te svote nahrani siromaha.

\section{MARUŠIN OBILAZAK SVETE ZEMLJE}

Maruša se u oporuci pohvalila da je bila „po svim svetim mjestima“ (ego fui per omnia loca sancta), što znači da je slijedila uhodanu rutu, a to potvrđuju i relikvije vezane uza Sveti Grob i rijeku Jordan, koje je ponijela kući. Budući da je itinerar potkraj 14. stoljeća bio visoko standardiziran, može se s priličnom sigurnošću rekonstruirati tijek njezina putovanja.

$\mathrm{U}$ to su vrijeme mletački poduzetnici, $\mathrm{u}$ „logističkoj suradnji“ $\mathrm{s}$ franjevačkim samostanom na Brdu Sion koji je bio zaštitnik svih katolika u Svetoj Zemlji, ${ }^{96}$ a pod budnim okom islamskih vlasti, razvili sustav koji je osiguravao plovidbu, hranu na brodu, smještaj, prijevoz po Svetoj Zemlji i sve drugo što je bilo potrebno hodočasnicima. Taj "paket usluga“, koji su na licu mjesta koordinirali kapetani mletačkih brodova, nije mogao otkloniti sve pogibelji, ali učinio je pu-

\footnotetext{
92 Testamenta notariae, sv. 5, f. 59r; TBD 3, 362v.

Testamenta notariae, sv. 13, f. 113rv.

Testamenta notariae, sv. $25,39 \mathrm{v}-40 \mathrm{r}$.

Dino MILINOVIĆ, 'To neizrecivo mjesto u kojemu je tri dana počivao Sin Čovječji': Bonifacije Dubrovčanin i obnova Svetog Groba, u: Umjetnost i naručitelji. Zbornik radova znanstvenog skupa 'Dani Cvita Fiskovića' održanog 2008. godine (ur. Jasenka GUDELJ), Zagreb: Institut za povijest umjetnosti, 2010., 74 . 
tovanje jednostavnijim i jeftinijim te dostupnim i manje bogatima. Kao posljedica toga, proštenja cvatu, ruta se „standardizira“, pišu se vodiči i izrađuju crteži s lukama i mjestima koja treba posjetiti evocirajući biblijske epizode koje su s njima povezane. ${ }^{97}$

U 1380-ima iz Venecije je u Sv. Zemlju godišnje plovilo između 300 i 600 ljudi. ${ }^{98}$ Sam prijevoz s hranom na brodu te transportom i pristojbama na kopnu koštao je 25 - 60 dukata po osobi, ovisno o tekućim cijenama i izabranoj „kategoriji smještaja“. ${ }^{99}$ Vitez Santo Brasca 1480. preporučio je onomu koji odlazi u Svetu Zemlju da ponese dvije torbe: jednu punu strpljenja i drugu sa 150 - 200 dukata, koliko je procijenio da je potrebno za bezbrižno putovanje osobi njegova staleža. ${ }^{100}$ Maruša je svakako putovala znatno skromnije, a ipak teško da je mogla proći s manje od 50 dukata za cijelo hodočašće. Za osobu njezina statusa to je bio golem novac i sama ga sigurno ne bi mogla namaknuti. Iz njezine oporuke saznajemo da je put financiralo nekoliko žena: vjerojatno najstarija od njih bila je Tomuša, zlatarova žena i majka Ruže Kotrulj; zatim sama Ruža Kotrulj, tada udana i majka nekoliko djece, i naposljetku Radica Bućin, prijateljica Marušine obitelji.

Iz Venecije se prema Svetoj Zemlji plovilo duž Jadrana i istočnog Sredozemlja, s uplovljavanjem u pojedine luke, ${ }^{101}$ gdje su se - kao i u Marušinu slučaju - mogli ukrcavati novi putnici. Nakon iskrcavanja u Jafi, ${ }^{102}$ hodočasnike se opskrbljivalo potrebnim papirima za kopneno putovanje. ${ }^{103}$ Obilazak Svete

$\overline{97}$ NEWETT, Introduction, 6-7; Arieh GR ABOÏS, Les pèlerins occidentaux en Terre sainte au Moyen Âge, Studi medievali, ser. III, 30, 1, 1989., 41-47; GANZ-BLÄTTLER, Andacht und Abenteuer, 96, 103-106; Colin MORRIS, The Sepulchre of Christ and the Medieval West From the Beginning to 1600, Oxford: Oxford University Press, 2005., 311-313; George SHUF FELTON, Introduction, u: The Stations of Jerusalem, Item 34, http://d.lib.rochester.edu/teams/text/shuffelton-codex-ashmole-61-stations-ofjerusalem-introduction, pristup 26. listopada 2016.

JACOBY, The economic impact, 710.

99 JACOBY, The economic impact, 710-711. Šaroliki podaci, pa i znatno niži iznosi koje donosi Ladić za Zadar u drugoj polovici 14. stoljeća mogu se protumačiti time da nije svaki legat morao pokriti sve troškove jednog hodočasnika već su se legati mogli zbrajati. Usp. LADIĆ, Prilog proučavanju hodočašćenja iz Zadra, 26.

100 NEWETT, Introduction, 9-10.

101 Ruta je išla iz Venecije uz istočnu jadransku obalu, dodirivala je mletačka uporišta na Krfu, Zanti, Modonu, Kreti i zatim preko Roda i Cipra vodila u Jafu. RÖHRICHT, Deutsche Pilgerreisen, 16. Pregled izvadaka iz djela stranih hodočasnika koji govore o jadranskoj obali i gradovima donose Jean RICHARD, Križari i putnici u srednjovjekovnoj Slavoniji, Croatica Christiana periodica, 10, 18, 1986., 27-39 i KUŽIĆ, Hrvatska obala u putopisima njemačkih hodočasnika.

102 Jafa je preuzela funkciju glavne hodočasničke luke nakon što je 1291. poharan Akon. JACOBY, The economic impact, 710.

103 Vrlo dobro organiziranu proceduru u prvoj polovici 15. stoljeća prikazuje PRESCOTT, Jerusalem Journey, 101-102. 
Zemlje odvijao se najvećim dijelom na magarcima. ${ }^{104}$ Počinjalo se s najbitnijim: posjetom crkvi Svetoga Groba, glavnom svetištu prema kojemu se obično nazivalo i cijelo hodočašće (ad Sanctum sepulcrum, ad sepulcrum Christi, al Sancto Sepulcro i sl.). ${ }^{105}$ Nastavljalo se s obilaskom drugih znamenitosti u Jeruzalemu i njegovoj neposrednoj okolici (Brdo hrama, Maslinska gora, brdo Sion). U drugom dijelu putovanja pohodilo se udaljenije biblijske lokalitete: Betlehem, Mrtvo More, Jerihon, rijeku Jordan (mjesto Kristova krštenja) i dr. ${ }^{106}$ Redovito su se hodočasnici još jednom vraćali u crkvu Svetoga Groba, kao najvažnije sveto mjesto i „pupak svijeta“,107 osim toga, posjet mjestima unutar i u blizini crkve donosio je barem devet potpunih oprosta, dvostruko više nego svi drugi lokaliteti u Svetoj Zemlji zajedno. ${ }^{108}$

\section{„SVETI SUVENIRI“ - SEKUNDARNE MOĆI IZ MARUŠINE ŠKRINJE}

Maruša je iz Svete Zemlje ponijela brojne „svete suvenire“. ${ }^{109}$ Budući da se u inventaru nabrajaju stvari koje ima, ali i određuje što s njima treba učiniti, tekst je ustvari hibrid inventara i oporuke, pa je nemoguće pouzdano reći koliko je čega bilo, ali svakako je nosila najmanje 7 kutijica (scatula), 5 jerihonskih ruža, 3

$\overline{104}$ PRESCOTT, Jerusalem Journey, 108-110; GANZ-BL ÄT TLER, Andacht und Abenteuer, 96. 105

Primjerice, Testamenta notariae, sv. 8, f. 44r, 47v; Distributiones testamentorum, sv. 5, f. 52r, 104 r; sv. 6, f. 33r. Zanimljivo je da je dubrovački trgovac i suknarski poduzetnik Andrija Martolov Volço (o. 1355.-o. 1429), dvostruki hodočasnik u Svetu Zemlju, u perivoju svog ljetnikovca izgradio „repliku“ crkve Sv. Groba. DIVERSIS, Opis slavnoga grada Dubrovnika, 105 i 183; KUŽIĆ, Hrvatska obala u putopisima njemačkih hodočasnika, 168. Takve su kapele bile popularne u Europi u 15. stoljeću, npr. jednu je izgradio hodočasnik William Way u samostanu Edington, a jedna i danas stoji uz kuću obitelji Adornes u Bruggeu. MORRIS, The Sepulchre of Christ, 319-320; Pnina AR AD, Pilgrimage, cartography, and devotion: William Wey's map of the Holy Land, Viator, 43, 1, 2012., 301-302. Prema svjedočanstvu dominikanca Razzija iz 16. stoljeća, na otočiću Daksi također je postojala jedna kapela po tom modelu, okružena drugim zgradama koje su predstavljale jeruzalemska sveta mjesta. Serafino RAZZI, La Storia di Ragusa (prir. Giuseppe GELCICH), Dubrovnik: Tipografia SerboRagusea A. Pasarić, 1903., 238; KUŽIĆ, Hrvatska obala u putopisima njemačkih hodočasnika, 68. SHUFFELTON, Introduction; za 15. stoljeće usporedi PRESCOTT, Jerusalem Journey, 115-170. O vjerovanju da je Sv. Grob „pupak svijeta“ vidi GANZ-BLÄTTLER, Andacht und Abenteuer, 9-10.

108 Kathryn M. RUDY, A Guide To Mental Pilgrimage: Paris, Bibliothèque de l'Arsenal Ms. 212, Zeitschrift für Kunstgeschichte, 63, 4, 2000., 495.

Izraz „sveti suveniri“ udomaćen je u stranoj literaturi, premda smisao tih hodočasničkih predmeta nije izazivanje ugodnih uspomena na put nego pohrana i prijenos duhovne moći. O tome vidi SUMPTION, Pilgrimage, 24-25; Gary VIKAN, Byzantine Pilgrimage Art, Dumbarton Oaks: Harvard University, 1982., 13; Georgia FRANK, Loca sancta souvenirs and the art of memory, u: Pèlerinages et lieux saints dans l'Antiquité et le Moyen Âge. Mélanges offerts à Pierre Maraval (ur. B. CASEAU, JeanClaude CHEYNET i V. RÉROCHE), Paris: Centre de Recherche d'Histoire et Civilisation de Byzance, 2006., 199. 
ili 4 vrpce i 7 pasova, 8 bočica i još dvije posude s vodom iz Jordana, što - sve u svemu - tvori priličnu zbirku "svetih predmeta“.

Ti se predmeti mogu ubrojiti u tzv. sekundarne moći (brandea) ili „,blagoslove“ (eulogiae, benedictiones), to jest stvari koje su dodirom sa svetime i same poprimile značaj relikvije. Bilo ih je vrlo različitih vrsta, od onih koje su sadržavale prah, zemlju, ulje ili vodu s nekog svetog mjesta do vlastitih predmeta posvećenih polaganjem na neko od loca sacra. U odnosu na "primarne“ relikvije, prednost im je bila ta što su se mogle neograničeno stvarati i umnožavati, pa su bile dostupne i običnim ljudima. ${ }^{111}$

Iz oporuke se saznaje da je Maruša nosila kući više kutijica (scatule magne, parve). Za jednu se kaže koje su relikvije u njoj (šest pojasa i četiri jerihonske ruže), a po komparativnim primjerima iz literature znamo da su se inače u takvim kutijama obično nalazili kamenčići s više svetih mjesta, kao što su Kristov Grob, Betlehemska špilja, Maslinska gora i Kalvarija, koji su se često kupovali već „"u kompletu“.12 Ako je ta pretpostavka točna, Marušini sitni moćnici namijenjeni privatnoj pobožnosti dopunjuju dubrovačku tradiciju javnog štovanja nekih od tih kamenih relikvija: riznica dubrovačke katedrale već je po najstarijem inventaru iz 1335. čuvala kamičak sa Svetoga Groba, a komadić stupa na kojem je bičevan Krist čuvao se u moćniku samostana sv. Klare; sredinom 16. stoljeća Bonifacije Stjepović Drkolica za vrijeme službe u Jeruzalemu nabavio je i darovao katedralnoj riznici dvije nove relikvije s tim kamenim fragmentima. ${ }^{113}$

$\overline{110}$ Na Marušinu se zbirku može primijeniti duhovita opaska G. Frank: ,ancient Christian pilgrims rarely traveled light" (FRANK, Loca sancta souvenirs, 193). Za usporedbu, Nompart de Caumont koji je u Svetoj Zemlji bio 1418. nabavio je više tkanina od svile, četiri trake s mjerom Svetoga Groba, tri svilene torbice i još jednu vezenu, 33 srebrna prstena i 12 srebrnih križeva koji su dotaknuli Sveti Grob, vrećicu s jeruzalemskom zemljom, 2 para zlatnih ostruga, 4 jerihonske ruže i bočicu s vodom iz Jordana. SUMPTION, Pilgrimage, 259-260.

111 VIKAN, Byzantine Pilgrimage Art, 10-12; Cynthia HAHN, Loca Sancta Souvenirs: Sealing the Pilgrim's Experience, u: The blessings of pilgrimage (ur. Robert OUSTERHOUT), Urbana-Chicago: University of Illinois Press, 1990., 85; Diana WEBB, Medieval European Pilgrimage, c. 700- c. 1500. Hounmills-New York: Palgrave Macmillan, 2002., 164; Gale R. OWEN-CROCKER, Brandea, u: Encyclopedia of Medieval Dress and Textiles, http://dx.doi.org/10.1163/2213-2139_emdt_SIM_000743 (pristup 26. listopada 2016.); Margaret GOEHRING, Textile Contact Relics, u: Encyclopedia of Medieval Pilgrimage, http://dx.doi.org/10.1163/2213-2139_emp_SIM_000231 (pristup 26. listopada 2016.); Cynthia HAHN, Issues in the Making and Meaning of Reliquaries, 400-circa 1204, University Park: Pennsylvania State University Press, 2012., 8. O srednjovjekovnom vjerovanju da se svetost osoba, predmeta i mjesta može prenositi dodirom vidi osobito VIKAN, Byzantine Pilgrimage Art, 4.

Relikvijarij koji je donio kući William Wey sadržavao je kamenčiće sa Svetoga Groba, Kristova stupa, s Kalvarije, s brda Tabor, s mjesta gdje je nađen Isusov križ i iz Betlehemske špilje. Fizički je sačuvana kutijica iz 6. stoljeća u Vatikanskim muzejima i jedna nedatirana, vjerojatno iz 17. stoljeća, u Danskom narodnom muzeju (Nationalmuseet). Anne Marie F LINDT, 'Holy' Souvenirs', Folk, 21-22, 1979.-1980., 199-200; VIKAN, Byzantine Pilgrimage Art, 18-19; MORRIS, The Sepulchre of Christ, 319; AR AD, Pilgrimage, cartography, and devotion, 308-309. 
Maruša je imala uza se i nekoliko jerihonskih ruža (rosa, rosa de Sancta Maria). Ta jednogodišnja pustinjska biljka iz porodice krstašica (Anastatica hierochuntica) prilagođena je pustinjskim uvjetima pa se savije u suhu kuglu kad joj je sjeme zrelo, a otvori i otpusti sjeme tek kad bude dovoljno vlage. Zbog te sposobnosti da iz suhoga stanja „oživi“, postala je simbolom Kristova uskrsnuća. S druge strane, „čudesnim“ otvaranjem povezivala se s porodom i koristila se kao amulet koji pomaže rodiljama ublažavajući bolove i štiteći njih i novorođenče od smrti. Odatle joj i ime „ruža Djevice Marije“, kao i na jednome mjestu u Marušinu inventaru. Zbog funkcije pri porodu, jerihonske su ruže bile vrlo tražene i cijenjene, pa su ih mnogi hodočasnici nastojali kupiti od beduina i ponijeti kući. ${ }^{114}$

Za vodu iz Jordana vjerovalo se da štiti od uroka i sukoba, stoga su je hodočasnici pili, u njoj prali ruke i noge, a neki se i kupali, u simboličnom činu obnove krštenja. ${ }^{115}$ Vodom su također punili razne posude koje su mogli ponijeti sa sobom, ${ }^{116}$ a koje se spominju i u Marušinu inventaru (trigestare... cum aqua Iordanis, fialae cum aqua Iordanis). U Jordanu se također običavalo močiti tkanine, koje su time postajale „relikvije“. ${ }^{117}$ Nije isključeno, ali ne može se pouzdano reći, da je tako bilo i s Marušinim ubrusom koji se spominje uz bočicu (parva trigestara cum una tobalea), a možda i s drugim ubrusima.

Dio „svetih stvari“ koje je Maruša ponijela iz Svete Zemlje možemo nazvati „moćima vlastite izrade“. I klerici i svjetovnjaci rado su nosili kući predmete kojima su premjerili sveta mjesta, npr. vrpce od svilenih i zlatnih niti s mjerama Svetoga Groba.

$\overline{113}$ Seraphinus Maria CERVA, Prolegomena in sacram metropolim Ragusinam: Editio princeps (prir. Relja SEFEROVIĆ), Zagreb-Dubrovnik: Zavod za povijesne znanosti HAZU, 2008., 445-446, 452, 462, 466-467, 495. O Bonifacijevoj djelatnosti u Svetoj Zemlji vidi KUŽIĆ, Hrvatska obala u putopisima njemačkih hodočasnika, 185; o istome, a napose o obnovi Svetoga Groba vidi MILINOVIĆ, 'To neizrecivo mjesto', 73-80. O ceremonijalnoj uporabi ovih relikvija u Dubrovniku vidi Nella LONZA, Kazalište vlasti: Ceremonijal i državni blagdani Dubrovačke Republike u 17. i 18. stoljeću, Zagreb - Dubrovnik: Zavod za povijesne znanosti HAZU, 2009., 301, 353-354, 409, 422-423.

114 PRESCOTT, Jerusalem Journey, 214; Suzy KNIGHT, Devotion, popular belief and sympathetic magic among renaissance Italian women: the Rose of Jericho as birthing aid, u: God's Bounty?: The Churches and the Natural World (ur. Peter CLARKE i Tony CLAYDON), Woodbridge: Ecclesiastical History Society, 2010., 134-143.

115 Prema zapisu milanskog kanonika Casole s kraja 15. stoljeća. CASOLA, Canon Pietro Casola's Pilgrimage to Jerusalem, 268; Pietro PORCASI, Introduzione, u: William WEY, Itinerarium peregrinacionis (1458) (prir. Pietro PORCASI), CISVA, 2010., XXII (https://www.academia.edu/1395361/ William_Wey_Itinerarium_peregrinacionis_1458_, pristup 30. listopada 2016.).

116 PRESCOTT, Jerusalem Journey, 158.

117 O toj praksi PRESCOTT, Jerusalem Journey, 158. 
Siromašniji hodočasnik mogao ih je i sam izraditi, pa je tako postupila i Maruša (cordella, craniça seu cordella cum qua mensuravi sepulcrum Christi). ${ }^{118}$ „Pobožno mjerenje“ustvari je bilo sastavni dio obreda na svetim mjestima koja je hodočasnik posjećivao. Mjerilo se vlastitim tijelom (prianjanjem cijelog tijela, rukama, prstima, stopom) ili trakom, koja je kroz materijalni oblik zadržavala i prenosila svetost toga mjesta. Te su se trake kasnije mogle nositi oko vrata, poput amuleta. ${ }^{119}$

Na sveta mjesta običavalo se polagati i druge predmete (npr. prsten, kruni$\mathrm{cu}$, hodočasničku značku) da bi se na njih prenijelo svojstvo svetoga. ${ }^{120}$ Spomen pojasa (cinguli de filis, cinguli de panno, vjerojatno i ura sive cimossis de scarleto que tetigit omnia loca Terre Sancte) u Marušinu inventaru vjerojatno se može vezati uz takvu praksu. Za usporedbu, Sava Nemanjić studeničkom je igumanu i prijatelju Spiridonu poslao, između ostaloga, mali pojas koji je položio na Sveti Grob pozvavši ga da ga uvijek nosi. ${ }^{121}$

Funkcija tih svetih predmeta ponesenih iz Svete Zemlje nije bila jednoznačna: bili su vezani uz osobnu pobožnost, uspomena na duhovno i tjelesno putovanje, pripisivala su im se profilaktička i ljekovita svojstva, nosili su društveni prestiž i bili rado primljen dar. Noseći u Dubrovnik „posvećene predmete“, Maruša je ispunjavala dug prema osobama u čije je ime hodočastila i s kojima je bila bliska.

„Sveti predmeti“ koji su iz Marušine ostavine stigli u Dubrovnik bacaju zraku svjetla i na osobnu pobožnost i relikvije u privatnim rukama, o čemu znamo vrlo malo: primjerice, Matej Nikolin Martinussio 1363. legatom je ostavio neku svoju relikviju opatiji sv. Marije Ratačke, ${ }^{122}$ a Marin Petrov Bocignolo 1394. u oporuci je opisao svoju relikviju zuba sv. Stjepana, ostavio novce za izradu relikvijara i naredio da ga se preda u Moćnik crkve sv. Stjepana. ${ }^{123}$

Dakako, Marušine cedulje i oporuka - primjeri „pragmatične pismenosti“ - ne opisuju detalje hodočašća koje bismo voljeli znati, no ipak pružaju niz iskoristivih obavijesti iz kojih se može steći toliko željeni uvid u osobno iskustvo konkretnog hodočasnika - $\mathrm{u}$ njegove motive, praktična iskušenja, pobožnost.

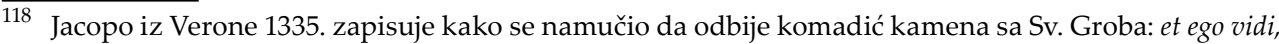
tetigi et de lapide cum difficultate accepi, quod durus lapis est (GANZ-BL ÄTTLER, Andacht und Abenteuer, 116). O takvoj praksi još iz 11. stoljeća vidi WEBB, Medieval European Pilgrimage, 164. in Jerusalem, Micrologus, 19, 2011., 134-150.

CASOLA, Canon Pietro Casola's Pilgrimage to Jerusalem, 261; PRESCOTT, Jerusalem Journey, 212 WEBB, Medieval European Pilgrimage, 165-166.

121 Danica POPOVIĆ, Eulogiae Terrae Sanctae of St Sava of Serbia, Balcanica, 56, $2014 ., 55$.

122 Opera pia, ser. 92 , sv. 16, f. 17 r.

123 Testamenta notariae, sv. 8, f. 55v.
} 
Ako je hodočašće „vježba u ovozemnom životu, koja čovjeka živo podsjeća na njegov konačni cilj prema kojemu je usmjeren“, ${ }^{124}$ Dubrovkinja Maruša svojim je putovanjem u Svetu Zemlju - premda to nije mogla znati - pripremila i svoj skori prijelaz s ovoga svijeta $u$ vječnost onostranoga, a nama na samrti ostavila jedinstveni izvor o ženskom hodočašću s kraja 14. stoljeća.

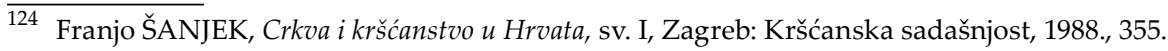


Rad Hrvat. akad. znan. i umjet. Razred za druš. znan. 52=529(2017) : 95-122

Prilog 1. Oporuka Maruše, kćeri Jakuše koja je žena Priboja Mazarak - prijepis

\section{TESTAMENTUM MARUSSE FILIE JACUSSE, UXORIS PRIBOY MASSARACH}

MCCCLXXXXIIII, indictione secunda, die tercio novembris. Ragusio. Coram nobili et sapienti domino Michaele de Babalio et iuratis iudicibus ser Andrea de Sorgo et ser Volço de Babalio. Nos presbiter Andreas de Lagusta et presbiter Nicola de Polato, testes iurati, unus in manibus alterius modo sacramentario testificamur quod infrascripta Marussa fecit in nostra presentia suum ultimum testamentum sic dicens. In nomine patris et filii et spiritus sancti, amen. Ego Marussa filia Jacusse facio meum testamentum cum sana mente et cum bona memoria existens set multum infirma corpore. In primis dimitto ecclesie Sancte Marie pro primitiis et decimis grossos VI. Et Sancto Blasio grossos III. Et si mater mea est viva quod res que sunt mee sint sue sicut est cingulum et obodcii et copertoria nova et qui (!) est parvior (!) inter omnes (!) volo quod detur fratri Paulo. Dimitto Radoslave uxori Obradi Arsuch si est viva perperos II. Et rogo dictam Radoslavam quod fatiat penitenciam pro me quam ego non complevi, quod vadat ad Sanctum Jacobum una die et quod non loquatur cum aliqua persona et quod det unum prandium uni pauperi. Et si mater mea est mortua comitto omnia mea Ruse uxori Ruschi de Cotrullo. Et dimitto dicte Ruse crocem pro amore quod portet et quod habeat animam meam in mente. Et dimitto Radiche Buchini unum ducatum. Et amite mee Lubne que stat in Gravossa dimitto unum yperperum. Et si quid est de rebus meis antiquis datur ei. Et Petrusse Priboi dimitto unam scatulam et unam rosam de Sancta Maria et unam cordellam. Dimitto in Sancto Leonardo yperperum unum. Et dimito (!) fratri Jacobo de Sibenicho patri meo spirituali unum ducatum. Audivi quod frater Benedictus vult ire ad Sanctum Jacobum et Romam, datur ei unum ducatum quando erit in recessu. Rogo vos Ruse et Radi, si mater mea est mortua, non dico ei set vobis dico quod faciatis dicere missas Sancti Gregorii pro anima mea, et si poteritis facere dicere in una die, faciatis. Et dimitto predicatoribus yperperum unum pro missa conventuali et unum prandium. Et si mater mea est mortua, quicquid fecit in suo testamento confirmo omnia. Et super hoc fatio meos pitropos Ruse uxorem Ruschi de Cotrulli et Radiçam uxorem Buchini. Et hoc est die XIX augusti sub anno Domini MCCCLXLXXXXIIII (!). Si est mater mea viva, quicquid est dans ista pro anima mea que sunt scripta, de residuo vivat sicut mater et domina mea.

In dicto testamento erant due cedule introcluse autenticate cum predicto testamento per dominum rectorem et iudices supradictos, quarum una est huius 
tenoris: Ego Marussa teneor dare Ruse uxori Ruschi Cotrulevich unum ducatum, volo quod habeat.

Altera enim est sequentis tenoris: In nomine Domini, amen. Iste sunt res Marusse dicte filie Jacusse quas habuit secum in galea. Primo unam capsam, in qua capsa erunt libre III gotoni (!). Item camisie IIII ${ }^{\text {or. }}$. Item de pipere modicum in una tobalea. Item unum capitale cum dimidio. Unum par sutelarium. Item I cingulum de scurlato et multe pecie de cusinis. Item scatule IIII ${ }^{\text {or }}$ magne et due parve et una tobalea. Item in una pera parva de filis III clu (?). Item in una scatula parva cinguli IIII de filis et duo de panno et IIII rose. Item unam lodicem et unam carpetam. Item unam capam. Item I par bisanciarum. Item duo pinuladi et duo coretta. Item una copertura capitalis in qua est farina. Item saccus I cum pane. Item due trigestare apud Bosicum cum aqua Iordanis et una parva cum una tobalea. Item una tobalea de duabus brachiis. Item unum sciphum de cupro. Item unum cingulum cum bursa et cultello et cruce argentea. Item sciphum I vitreum. Fialas VIII cum aqua Iordanis. Item unum urceum cum simça. Item I barile. Item pilercum I et una (storfil cancell.) forfice. Item scutellas qunque de (capro cancell.) cipro (!). Item tunica que dicitur codmaniça. Item criniales (?). Et istas res suprascriptas dimito in manibus Bosichi qui fuit puer de ser Goççicho, qui det ipsas matri mee et ipsa recipiat. Et si mater mea esset mortua, quod dicte res dentur Ruse Cotrulevich et Radice Buchini quod ipse faciant pro anima mea. Volo quod dabitis dicto Bosich unam camisiam et unum par bracis et unum sudarium de meis quia fuit mihi sicut frater in infirmitate mea. Volo quod detur una scatula Margarite filie Ruse et una alia Nicolete sorori sue scatula parva. Et Ruse detis unam craniçam seu cordellam cum qua mensuravi sepulcrum Christi et unam rusam et unam scatulam date Cuite vicini mee que stat ad parietem domus mee et unam craniçam et fili quibus consuitur quia eius sunt. Et detis unam scatolam Lubne quam vos vultis et craniçam unam et unam rosam, et unam scatulam Miladne Gradoevich que non est pulcra. Et sciat Miladna quod non vendidi tobaleam nisi grossorum $\mathrm{XV}$, Deus scit, tu tamen scis quod teneris mihi dare grossos septem cum dimidio, et alios VII cum dimidio petas a matre mea, si est viva, quod det sibi aut peccuniam aut terminum. Et si mater mea est mortua, vadat Radiça Buchini ad Antonium pelliçarium quod ipse recipiant (!) istas res. Et si debent quid dare mihi Gradoeivi (!) pro tela quam receperunt a me, si non dederint, petat Ruse Cotrulli et Radiça supradicta. Et date Iursicho de Ruse istum garbis. Et date scatulam unam Goyne Velegni (?) miscitari (?). Et Ratche vicine mee dare unam uram (?) sive cimossem de scarleto que tetigit omnia loca Terre Sancte et unam rosam que est minor. Et de aliis rebus que remanent dari dite sicut placet vobit. Peto a Miladna quod parcat mihi si aliquid 
dixi sibi malum, quod mali homines posuerunt inter nos. Et si sana fuissem ravisemus melius quam aliquando. Set propter amorem dono vobis istam scatulam quod recordemini de me. Ego rogavi Deum pro vobis, rogate vos pro me. Rogo Ruse Cotrulli quod fatiat pro anima mea quantum potest quia ego fui per omnia loca sacra pro te et pro matre tua, similiter pro Radiça. Rogo vos date isti famulo sicut scribo, quod habeat sicut veniet cum istis rebus quinque brachia cum dimidio de tela. Hoc autem testamentum etc.

In margine: Extractum et datum.

Državni arhiv u Dubrovniku, Testamenta notariae, sv. 8, f. 58r-59r. 


\section{Prilog 2. Oporuka Maruše, kćeri Jakuše koja je žena Priboja Mazarak - faksimil}

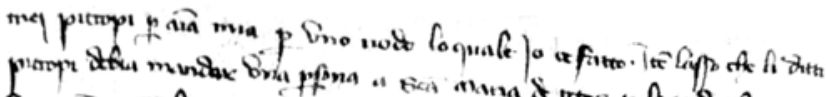

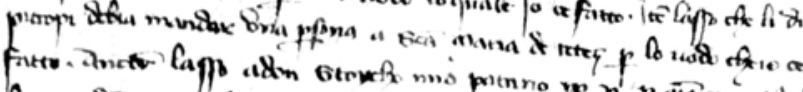

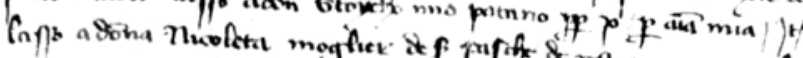

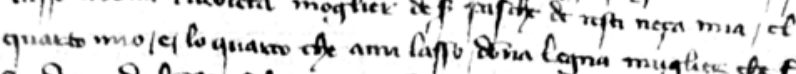

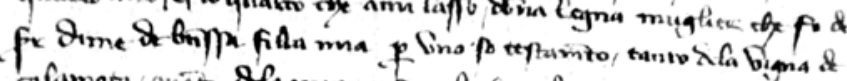

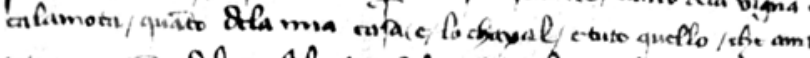

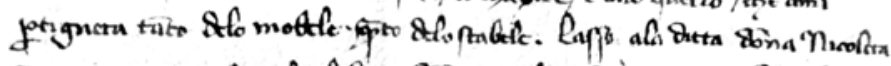

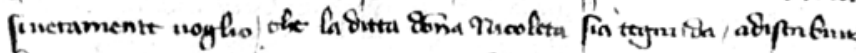

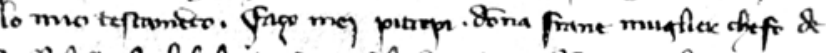

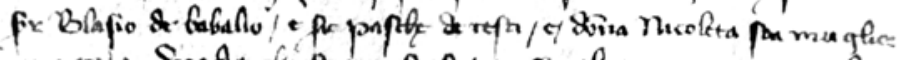

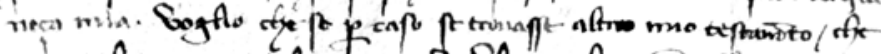

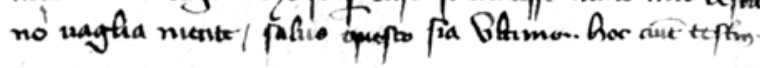

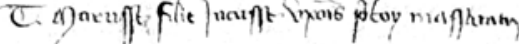

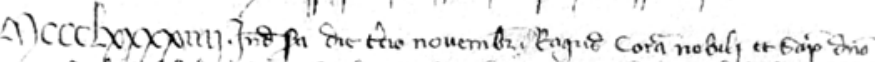

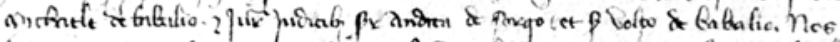
PME

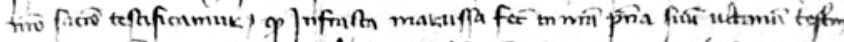

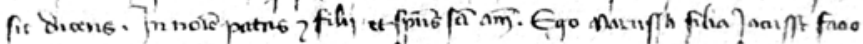

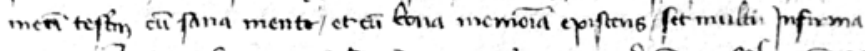

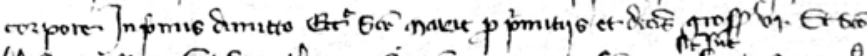

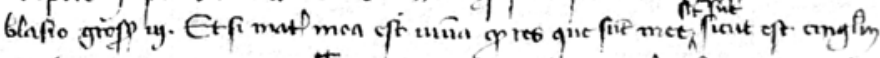

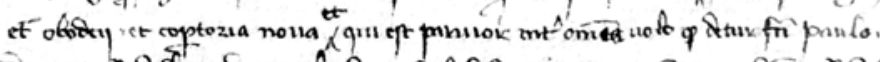

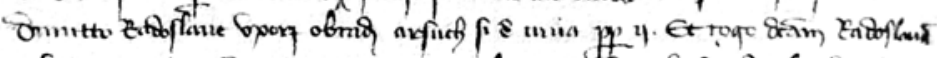

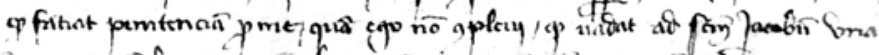

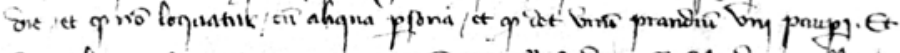

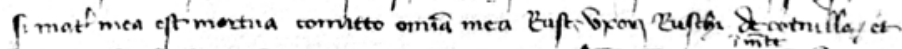

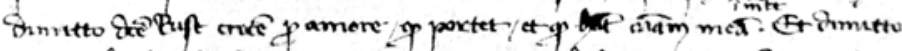

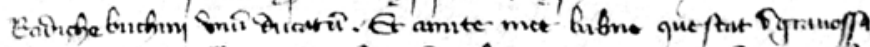

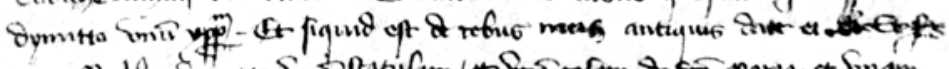

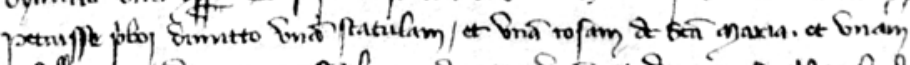

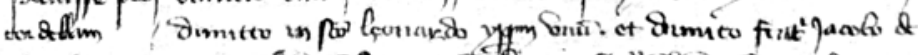

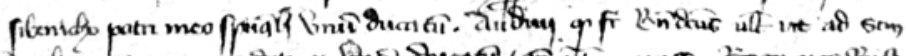

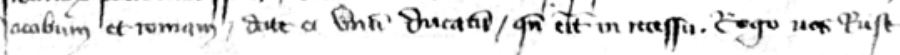




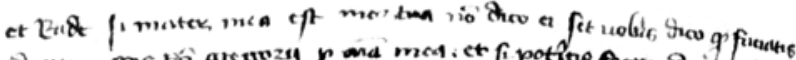

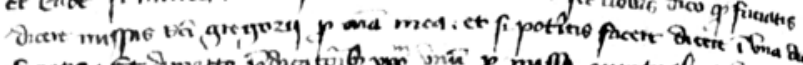

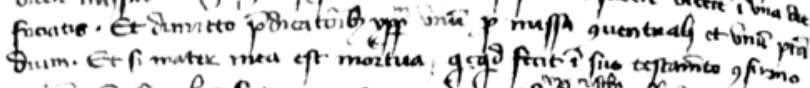

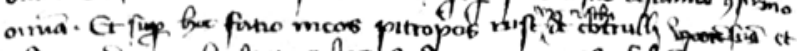

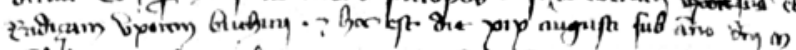

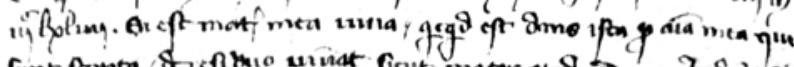

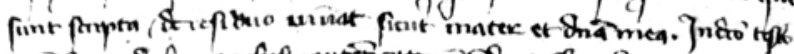

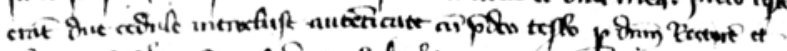

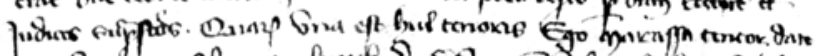

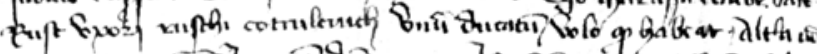

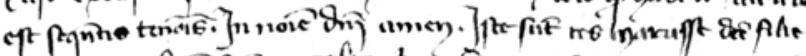

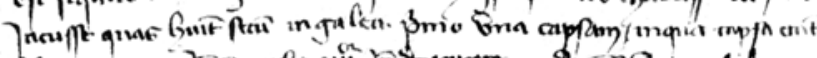

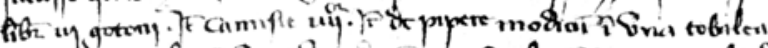

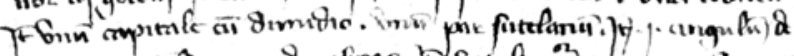

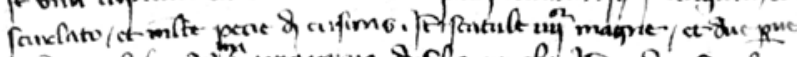

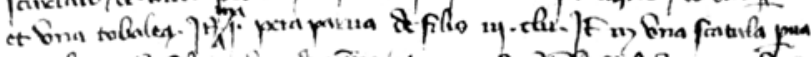

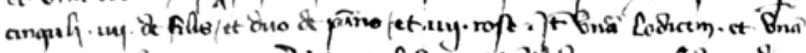

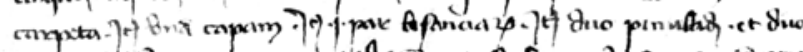

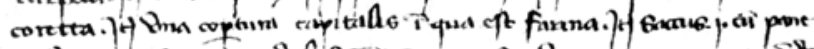

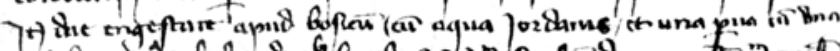

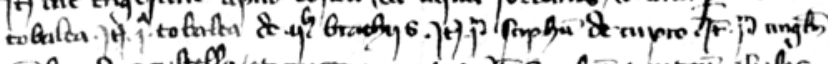

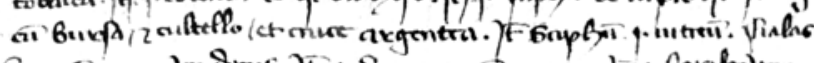

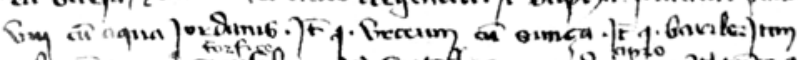

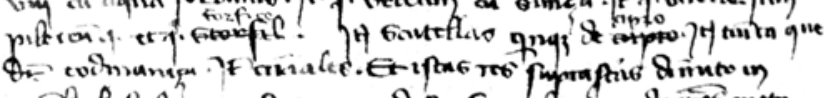

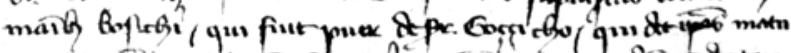

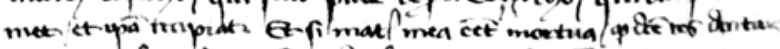

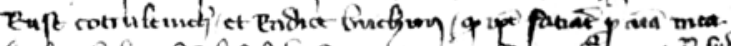

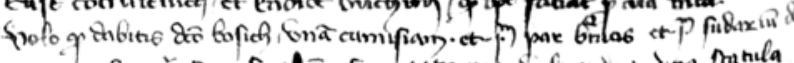

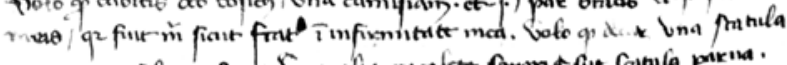

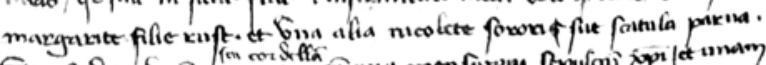

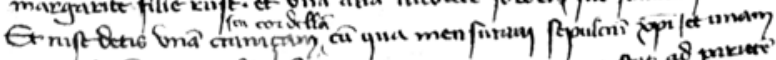

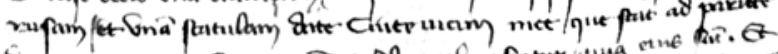

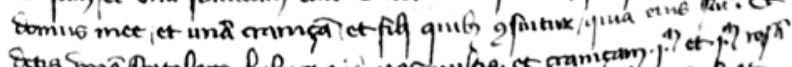

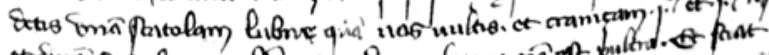

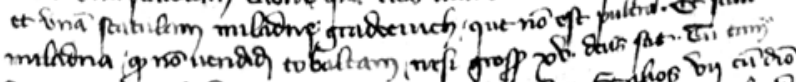

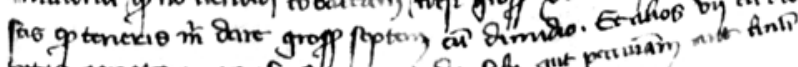

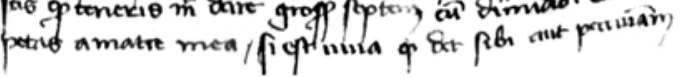

Slika 2.- 58v 


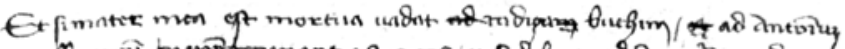

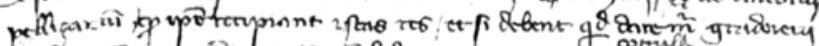

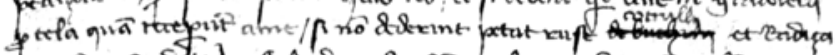

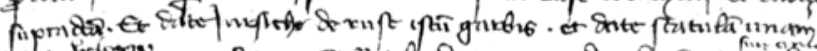

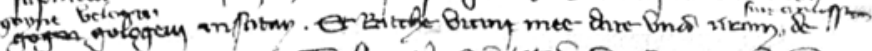

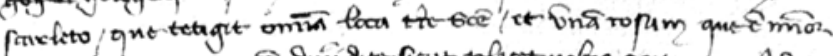

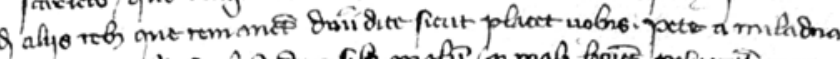

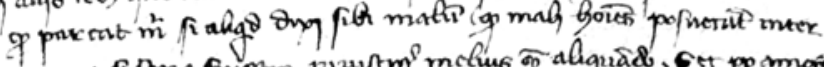

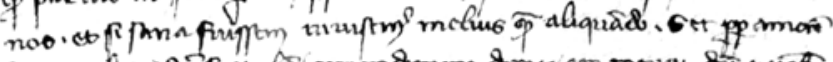

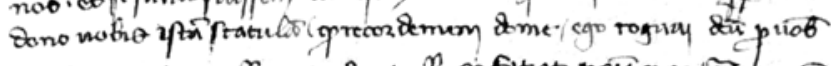

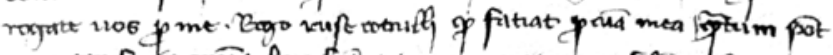

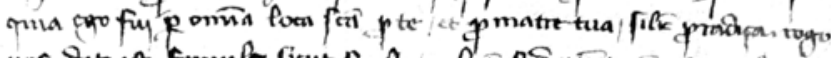

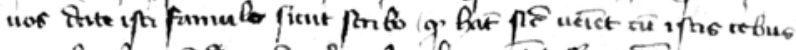

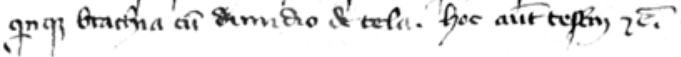

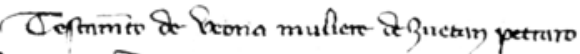

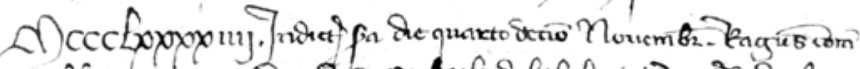

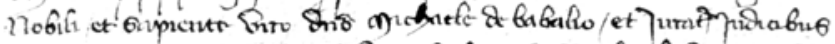

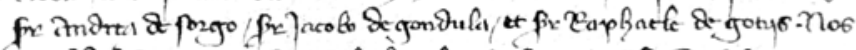

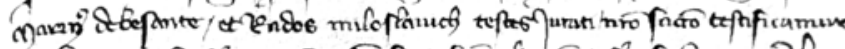

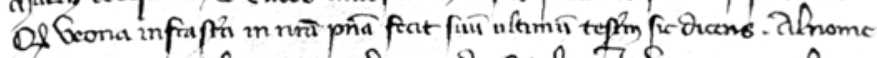
Q

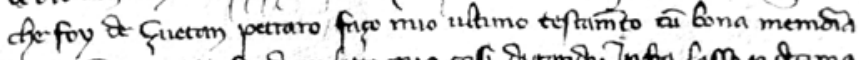

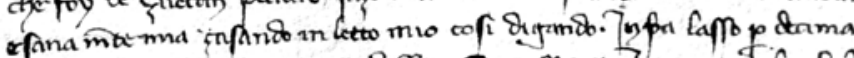

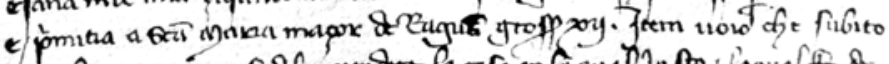

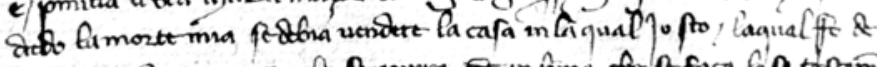

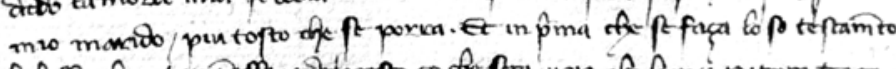

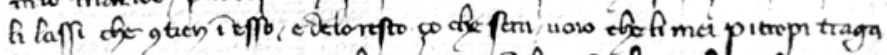

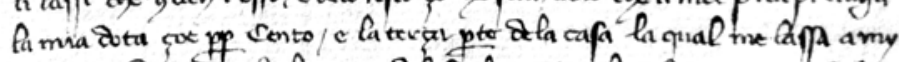

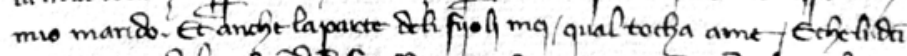

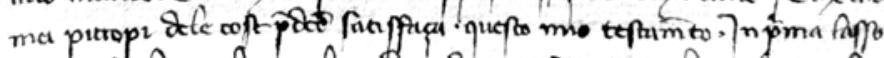

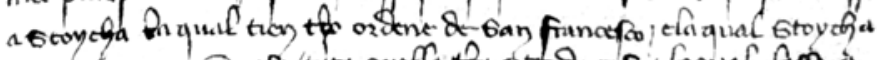

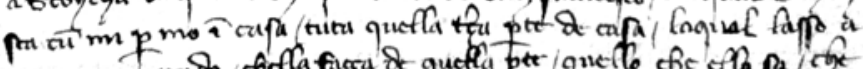

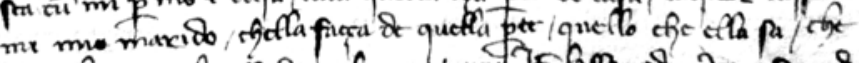

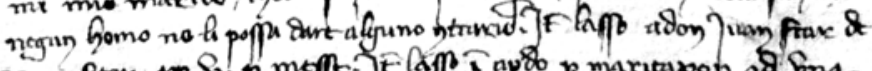

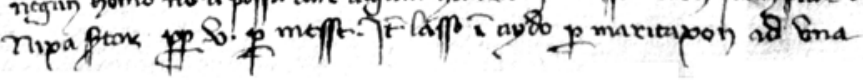

Slika 3.- 59r 


\section{Summary}

\section{Ego fui per omnia loca sancta: The Pilgrimage of Maruša, a Ragusan Woman, to the Holy Land in 1394}

On the ground of the last will of a Ragusan woman called Maruša, made aboard a ship sailing back from the Holy Land in 1394 and today filed in the State Archives of Dubrovnik, several aspects of this particular pilgrimage are examined, as well as some more general issues of female piety and pilgrimages in the Late Middle Ages.

Maruša was an unwed member of a middle-class commoner family. On the basis of last wills and other archive documents, Maruša's social network is reconstructed, paying special attention to the women upon whose prompting she travelled to the Holy Land and who co-financed her journey. Besides documenting Maruša's pilgrimage overseas, her last will reveals a rarely recorded practice of penitential pilgrimages to the churches in the very vicinity of Dubrovnik.

Together with a group of Ragusans, Maruša embarked on a Venetian pilgrim galley probably in the early summer of 1394. A couple of months later, on her voyage back she fell ill and soon died. On her death bed, Maruša made her last will and inventory of her belongings, providing the historian with a useful insight into the travel equipment of the time. Various details from Maruša's will confirm that she followed the standard itinerary, as known from many accounts of the pilgrims to the Holy Land in the late fourteenth and fifteenth century. Most interesting are the data on the "holy souvenirs" (brandea), acquired or shaped during her visit to the Loca Sancta: roses of Jericho, recipients with the water of the River Jordan, ribbons by which she measured the tomb of Jesus, belts laid down to the Holy Places, and other eulogiae.

The transcript of Maruša's last will is given in the appendix.

Keywords: Dubrovnik; Holy Land; Middle Ages; pilgrimage; female piety; brandea 